Article type: Research paper

Date text submitted: February 2019

Number of words in your main text and tables: $\sim 8,900$

Number of figures: 15

Number of tables: 2

A novel finite element approach for large-scale urban underground hydro-thermal modelling A case study of the Royal Borough of Kensington and Chelsea, London

Author 1

Asal Bidarmaghz ${ }^{\bowtie}, \mathrm{PhD}$

Research Associate

Department of Engineering, University of Cambridge, Trumpington Street CB2 1PZ, UK

Author 2

Ruchi Choudhary, $\mathrm{PhD}$

Reader in Architectural Engineering_Department of Engineering, University of Cambridge, Trumpington Street CB2 1PZ, UK

Data-centric Engineering, Alan Turing Institute, UK

Author 3

Kenichi Soga, $\mathrm{PhD}$

Chancellor's Professor

Department of Civil and Environmental Engineering, University of California, Berkeley, USA

Author 4

Holger Kessler, MSc, FGS

British Geological Survey, Keyworth, Nottingham NG12 5GG, UK

Author 5

Ricky L. Terrington, MSc, CGeog (GIS)

British Geological Survey, Keyworth, Nottingham NG12 5GG, UK

Author 6

Stephen Thorpe, BSc

British Geological Survey, Keyworth, Nottingham NG12 5GG, UK

Full contact details of the corresponding author

Asal Bidarmaghz, Research Associate

Department of Engineering, University of Cambridge, Trumpington Street, Cambridge CB2 1PZ, UK

E-mail: ab2492@cam.ac.uk, asalbiarmaghz@gmail.com 


\begin{abstract}
The urban underground of dense cities is increasingly exploited for various purposes due to the significant rise in urban populations. Past research has shown that underground activities have a significant impact on local subsurface temperatures. However, the resulting spatial variabilities of ground temperature elevations at a cityscale are not well understood. This is due to lack of sufficient information and modelling complexity at such large scales. This paper presents a novel semi 3D finite element approach to evaluate the temperature rise in the ground due to heat sources such as residential basements and train lines across an entire district. This novel modelling approach is capable of capturing the combined influence of underground built environment characteristics, coupled with ground properties on ground temperature elevations at large-scales. It is observed that density and distribution of heat sources are critical parameters in ground temperature evaluation in highly impermeable ground such as London Clay Formation. The extent of ground thermal disturbance, however, is mostly affected by geological and hydrogeological characteristics in permeable ground. The locality of temperature rise and potential ground energy within immediate impermeable ground surrounding heat sources versus significantly large extent of ground thermal disturbance in permeable ground highlights the significant spatial dependency of ground thermal state and geothermal potential at the studied site. Results show that resilient planning of underground developments and sustainable geothermal exploitation in the short and long-term requires large-scale ground thermal modelling using local ground and underground built environment characteristics.
\end{abstract}

\title{
List of Notations
}

\begin{tabular}{|c|c|}
\hline$A_{s}$ & annual air swing $\left[{ }^{\circ} \mathrm{C}\right]$ \\
\hline$C_{p, e f f}$ & effective heat capacity of porous material $[\mathrm{J} /(\mathrm{kgK})]$ \\
\hline$d z$ & vertical distance between the planes $[\mathrm{m}]$ \\
\hline g & gravitational acceleration vector $\left[\mathrm{m} / \mathrm{s}^{2}\right]$ \\
\hline K & ground permeability $\left[\mathrm{m}^{2}\right]$ \\
\hline$k_{h}$ & ground hydraulic conductivity $[\mathrm{m} / \mathrm{s}]$ \\
\hline$k_{v}$ & vegetation coefficient [-] \\
\hline$n$ & $\mathrm{n}^{\text {th }} 2 \mathrm{D}$ plane \\
\hline$p_{f}$ & pore pressure $[\mathrm{Pa}]$ \\
\hline$q_{0, u p}$ & upside out of plane heat flux [W] \\
\hline$q_{0, \text { down }}$ & downside out of plane heat flux [W] \\
\hline$t$ & time of the year [day] \\
\hline$t_{0}$ & coldest temperature day from January $1^{\text {st }}[$ day $]$ \\
\hline$T_{\text {ground, mean }}$ & ground annual average temperature $\left[{ }^{\circ} \mathrm{C}\right]$ \\
\hline$\underline{T}$ & temperature field in the ground $\left[{ }^{\circ} \mathrm{C}\right]$ \\
\hline $\mathbf{v}$ & Darcy velocity field $[\mathrm{m} / \mathrm{s}]$ \\
\hline $\mathrm{z}$ & depth in the ground $[\mathrm{m}]$ \\
\hline$\alpha$ & ground thermal diffusivity $\left[\mathrm{m}^{2} / \mathrm{s}\right]$ \\
\hline$\varepsilon$ & Porosity [-] \\
\hline$\lambda_{\text {eff }}$ & effective thermal conductivity of porous ground $[\mathrm{W} / \mathrm{mK}]$ \\
\hline$\lambda_{f}$ & groundwater thermal conductivity [W/mK] \\
\hline$\lambda_{m}$ & solid material thermal conductivity $[\mathrm{W} / \mathrm{mK}]$ \\
\hline$\mu_{f}$ & groundwater dynamic viscosity [Pa.s] \\
\hline$\rho_{\text {eff }}$ & Effective density of porous material $\left[\mathrm{kg} / \mathrm{m}^{3}\right]$ \\
\hline$\rho_{f}$ & groundwater density $\left[\mathrm{kg} / \mathrm{m}^{3}\right]$ \\
\hline
\end{tabular}




\section{Keywords}

Large-scale ground modelling, geothermal potential, heat source, built environment, geology, hydrogeology. 


\section{Introduction}

With the rise in urban populations and significant improvements in construction technologies, the number of subsurface structures is expected to grow in the next decade, leading to so-called subsurface congestion. This trend, in particular, is observed in mega cities such as New York, Tokyo, Singapore, Hong Kong and London. The urban underground of dense cities is exploited for various purposes such as transport, additional residential/commercial spaces, storage, and industrial processes. For example, about 4,600 residential basement development proposals were submitted in seven boroughs in London between 2008-2017, indicating the rapid rate of the urban underground construction (Baldwin et al., 2018, Batty et al., 2018).

Recent studies have clearly demonstrated that anthropogenic heat flow from building and basements influences the subsurface temperatures, especially in the proximity of urban aquifers (Attard et al., 2016a, Attard et al., 2016b, Benz et al., 2015, Epting et al., 2017, Epting et al., 2013, Ferguson et al., 2004, Ferguson et al., 2007, Menberg et al., 2013, Mueller et al., 2018, Rivera et al., 2017). A study by Ferguson et al. (2004) was one of the first to examine the heat flux from buildings to the ground in Winnipeg, Canada. It showed the extension of the ground temperature anomaly to be about $130 \mathrm{~m}$ vertically and $50 \mathrm{~m}$ laterally outward from the building, with a temperature increase of over $2^{\circ} \mathrm{C}$ in 100 years. Benz et al. (2015) and Menberg et al. (2013) quantified the anthropogenic heat fluxes into the subsurface using an analytical heat flux model for two cities in Germany. They showed that, at the city-scale, basements are the second most dominant sources of heat within the subsurface after ground source heat pump systems $\left(3.61 \pm 3.37 \mathrm{~W} / \mathrm{m}^{2}\right.$ in Karlsruhe, and $0.57 \pm 0.47 \mathrm{~W} / \mathrm{m}^{2}$ in Cologne). Epting et al. (2013) evaluated the thermal potential of groundwater bodies in Basel (Switzerland) using a deterministic modelling approach. Their results revealed the significant influence of underground structures on groundwater temperature. A recent proof-of-concept numerical study of a London Borough showed ground temperature elevations range between $1-5.5^{\circ} \mathrm{C}$ as a result of continuous heat losses from basements to the ground (Bidarmaghz et al. 2018). The extent of temperature elevation in the surrounding ground (vertical and horizontal) was found to vary significantly as a function of local geological variations, the thickness of the permeable layer, the groundwater regime and velocity around underground structures. In general, the amount of heat loss from heated residential basements to the ground was found to be comparable in magnitude to the heat losses from building façades to the air.

Another contributor to the ground temperature elevation is the underground transport system. When high ambient temperatures are combined with heat emitted from train braking and passenger traffic, the temperatures of tunnels and platforms rise substantially above tolerable levels. There are examples of subway systems around the world suffering from overheating problems (Ampofo et al., 2004, Cockram et al., 1976, Furfano et al., 2018, Stephen, 2016). The report by Ampofo et al. (2004) recorded temperatures of more than $37^{\circ} \mathrm{C}$ within the London underground network when the ambient temperature was around $30^{\circ} \mathrm{C}$ in summer. Cockram et al. (1976) showed $4-5^{\circ} \mathrm{C}$ temperature increase in the surrounding ground of the Victoria Line in London, less than 10 years after it opened. Mortada et al. (2018) used a multi-scale co-simulation framework to show the significant amount of heat that can be extracted from overheated underground subway tunnels in London. Data from work by Furfano et al. (2018) revealed temperatures of more than $37^{\circ} \mathrm{C}$ at some platforms in New York. Rymarov et al. (2017) reported heat loss of about $2-5 \mathrm{~W} / \mathrm{m}^{2}$ for a tunnel embedded 5-10 m below the surface.

The focus of recent research on urbanization and shallow subsurface has highlighted the significance of temperature anomalies within the subsurface, due to human activities, and the existing geothermal potential (Arola et al., 2014, Hähnlein et al., 2013, Herbert et al., 2013, Zhu et al., 2010). The work by Rivera et al. (2017) on the estimation of geothermal potential in urban areas showed that for typical conditions in central Europe, each additional degree of urban ground temperature rise could save around $4 \mathrm{~m}$ of Ground Source Heat Pump (GSHP) system borehole length for the same heating power supply. Studies of the inner-city of London by Mortada et al. (2018) and Zhang et al. (2014) showed that a large proportion of buildings could support their own heating demand using GSHP technology without losing control of ground thermal capacity. At the same time, the increased number of heat waves globally indicate a significant increase in cooling demand during summer (Arola et al., 2014, Peters, 2018, Chua et al., 2010, Lund et al., 2005), for which the utilization of ground as a heat sink will not be efficient unless the existing temperature elevations in the ground are known and utilized sustainably. Furthermore, and as aforementioned, studies have already shown that local heat sources, coupled with hydrogeological properties of the shallow ground have a significant influence on the magnitude of local ground temperature elevations. This not only implies that the utility of geothermal systems varies across a city, but also 
indicates that planning laws with respect to underground heated structures and policies related to geothermal systems must be locally tailored to ensure long-term thermal balance of the ground.

There is a clear need to understand the spatio-temporal variability of ground temperatures under both current and future scenarios as it will enable resilient planning of underground activities and geothermal exploitation in cities for both the short and long-term. Yet, most city-scale studies on geothermal potential assume uniform ground temperatures and do not account for local heat sources. Despite detailed studies on underground structures and heat emission to the subsurface, studies on spatial variations of ground temperature elevations are scarce. As an example, Attard et al. (2016a) have shown the significant cumulative impact of $7.5 \mathrm{~m}$ plus deep underground structures in contact with groundwater on the subsurface temperatures in the city of Lyon, France. Mueller et al. (2018) presented a combined monitoring and modelling technique to simulate the current thermal state of four groundwater bodies in the city of Basel, Switzerland, by means of temperature wells and numerical 3D groundwater flow and heat transport models in saturated ground. However, the impact of ground properties in combination with characteristics and distribution of underground structures (e.g., tunnels and basements) on spatial variations of ground temperatures is not studied yet.

There are several challenges that hinder modelling and quantification of spatial variations of ground temperature elevations in cities. Some of these are: (1) limited access to geological and hydrogeological details of the ground, (2) lack of established/reliable information of subsurface built environment, (3) the computational cost of 3D groundwater flow and heat transport models at such large scales, and (4) sparse ground temperature measurements that limit the potential of calibrating model outputs to reality. The paper tackles the first three challenges, and thereby creates the foundation of tackling challenge 4. In doing so we demonstrate the collection and integration of data from diverse sources and their assimilation at requisite resolution (e.g., geology, hydrogeology, depth/number of underground structures, etc.). The main novelty of the work lies in a new finite element approach, which enables us to tackle the size of the problem. We illustrate the complete steps of the modelling process and the outcomes through an illustrative study of the Royal Borough of Kensington and Chelsea (RBKC), which has a surface area of about $12 \mathrm{~km}^{2}$ (see Figure 1). At this initial stage, we limit the study to two main underground heat sources in the area: heated residential basements and train tunnels.

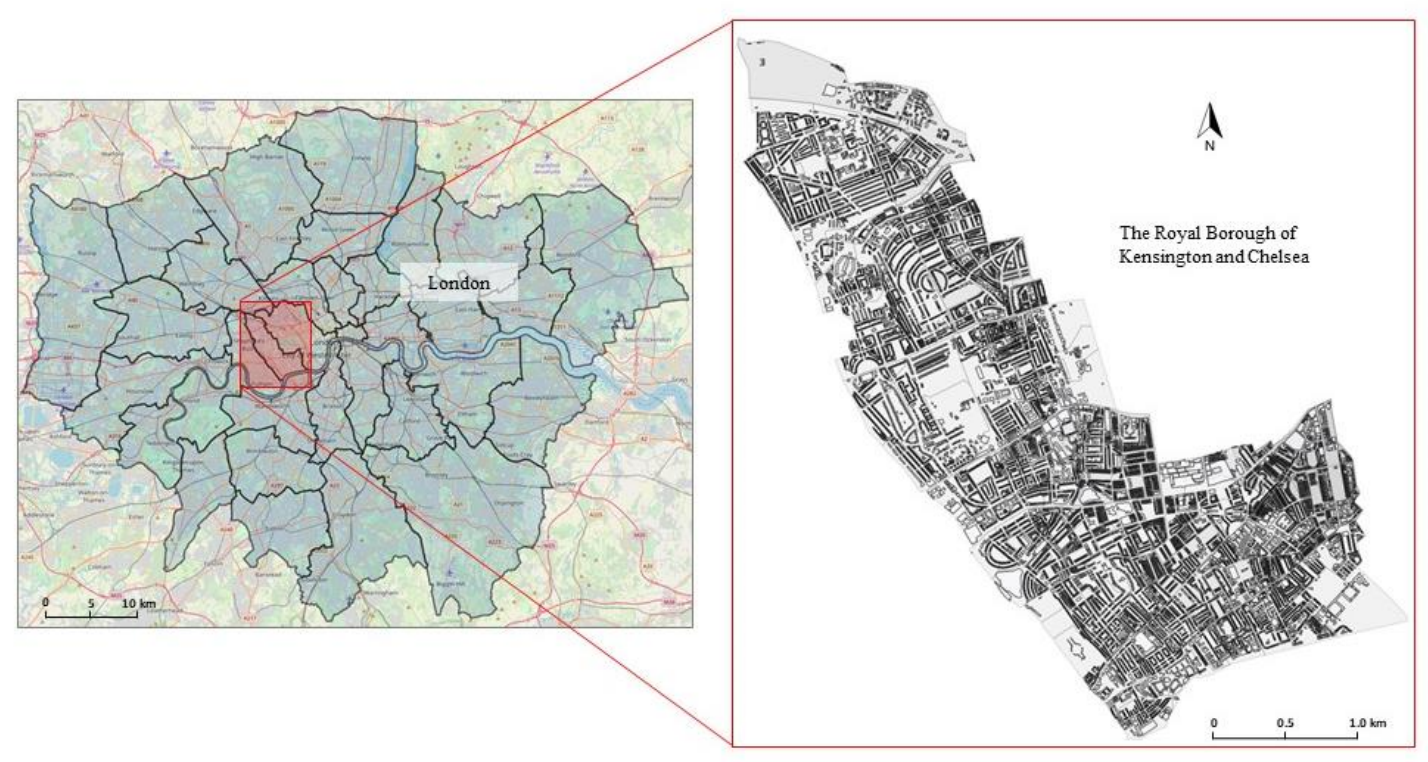

Figure 1. Location of the study area (RBKC) in Greater London.

\section{Urban underground properties}

Recent developments in mapping databases provide extensive high-resolution information on the above ground built environment. These include exact location and type of landuse, built structures, their height, construction type and age, and current use. The extensive use of these databases for city-scale analysis of energy systems is shown in work by Choudhary (2012) and Booth et al. (2012). However, similar levels of information for 
subsurface structures is still nascent and not readily available. Thus, we gather information from diverse sources to assimilate the properties of the subsurface built environment of RBKC. The key sources of information are: (a) commercial mapping databases (GeoInformation, 2017a, GeoInformation, 2017b), (b) RBKC planning and building control departments (RBKC, 2018), and (c) Transport for London (TfL).

\subsection{Residential basements}

Residential basements are one of the main contributors to the subsurface temperature elevation (Benz et al., 2015, Menberg et al., 2013). Basements are typically built on expensive lots, where the owners have reached the maximum above-ground space allowed. The Royal Borough of Kensington and Chelsea (RBKC) is known for large utilization of underground spaces, particularly as residential basements. There were about 4,600 basement development proposals made in seven boroughs in London between 2008-2017 (derived from the information provided by each borough's planning portal-Figure 2-a). Around 1,300 of these applications were in RBKC, where basement developments were spread across the whole borough, demonstrating one of the highest basement development rates per household in the country. These applications included around 676 standard basements (single level, mostly under Terrace houses), 279 large basements (two levels) and around 67 mega basements (three levels or more- up to the depth of 18m) (Baldwin et al., 2018, Batty et al., 2018). Furthermore, a review of the geo-mapping dataset provided by GeoInformation (2017a) confirmed the existence of 13,000 known residential basements in RBKC (see Figure 2-b). RBKC comprises about 22,000 residential buildings, $80 \%$ of which are Terrace houses. $75 \%$ of residential basements in RBKC was found in Terrace houses. Knowing the most dominant building typology (Terrace houses) in the borough and their corresponding building age, the characteristics of their basements were investigated by reviewing the applications submitted to the planning and building control portal (RBKC, 2018). A comprehensive review of RBKC's planning and building control portal revealed that for most of the terrace houses, basements are single level and their floor area is similar to the building footprint. Therefore, the floor area per standard basement was assumed to be about $50 \mathrm{~m}^{2}$, reflecting the basement of a typical two-bedroom terrace house and an average ceiling height of $3 \mathrm{~m}$. A wall and slab thickness of $0.4 \mathrm{~m}$, made of concrete could be considered as standard for these basements (RBKC, 2018). The basements were assumed to be kept at a comfortable temperature level of $18^{\circ} \mathrm{C}$ throughout the year (Lane, 2011).

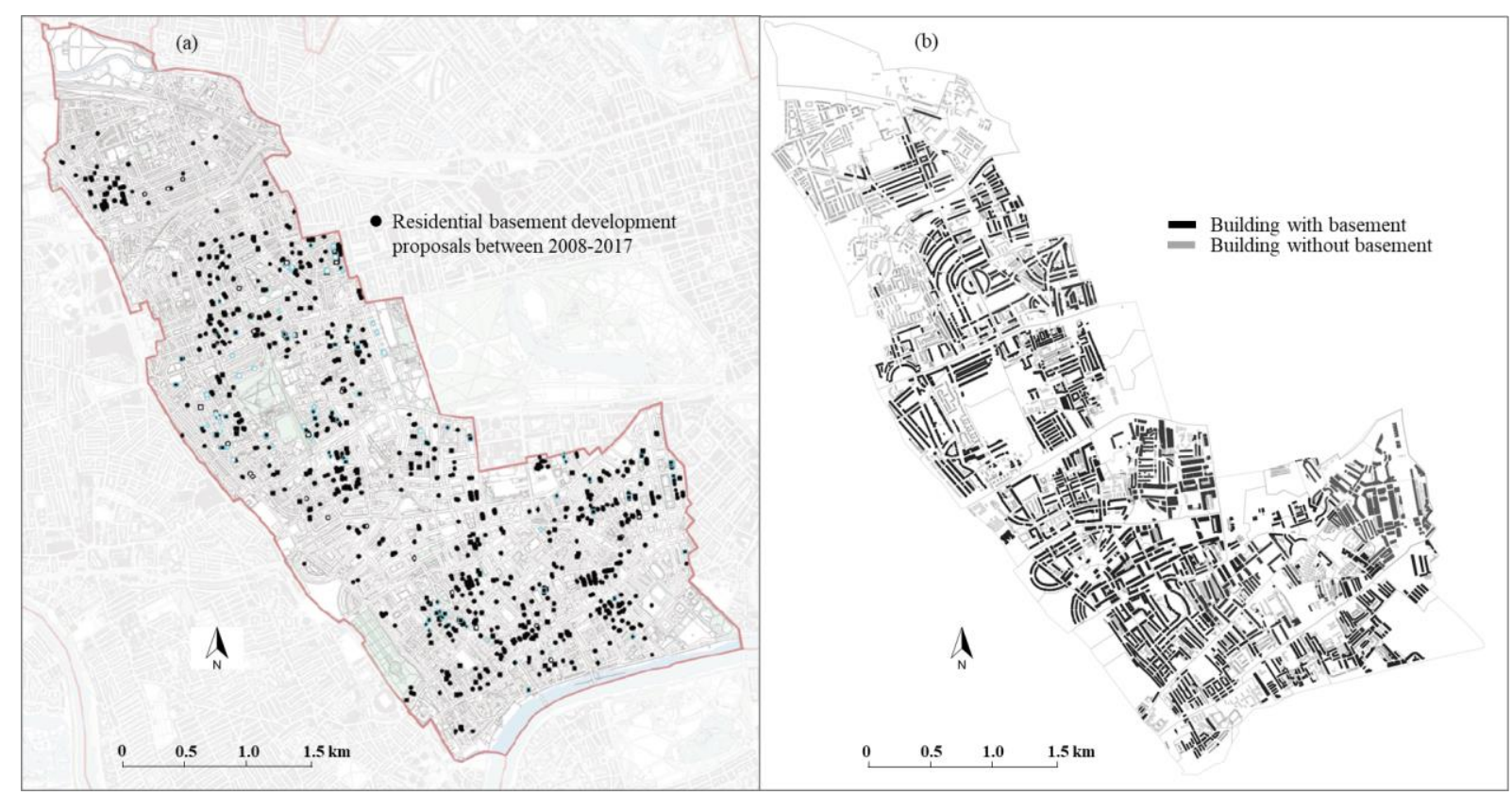

Figure 2. The Royal Borough of Kensington and Chelsea: a) basement developments between 2008 and 2017, b) distribution of the residential buildings with/without basements. 


\subsection{Train tunnels}

The temperatures in subways is typically warmer than the outside air temperature due to the operation of railway systems. Tunnel and platform temperatures can rise substantially above tolerable levels in summer time leading to passenger's thermal discomfort. In London, where ambient temperature can reach $30^{\circ} \mathrm{C}$ in summer, temperatures of more than $37^{\circ} \mathrm{C}$ have been recorded on some trains within the London underground network (Ampofo et al., 2004). Similarly, some platforms in New York metro show temperatures as high as $38^{\circ} \mathrm{C}$ in summer time (Furfano et al., 2018). By analyzing the platform air temperature data gathered by London Underground (LU) since 2005, Gilbey et al. (2011) introduced an approximate relationship between platform and outside air temperatures as: $\mathrm{T}_{\text {platform }}=0.36 \mathrm{x} \mathrm{T}$ outside +19.5 . It should be noted that tunnel air temperatures are typically $2-3^{\circ} \mathrm{C}$ cooler than the platform air temperatures. This is due to the higher heat dissipation rate during acceleration and braking and therefore, heat concentration at the platforms (Gilbey et al., 2011).

The Royal Borough of Kensington and Chelsea is well served by public transport services (Figure 3-left). The maximum temperature recorded in the peak summer time reaches above $30^{\circ} \mathrm{C}$ for most of the lines in the borough (Stephen, 2016). Train lines, therefore, are expected to be one of the main contributors to the ground temperature elevation in RBKC. In total, about $15 \mathrm{~km}$ of the underground railway network is running underneath the borough mostly comprising two circular tunnels with an average diameter of $4.5 \mathrm{~m}$ (Transport for London, 2018). The linear relationship between tunnel/platform temperatures and outside air temperature developed by Gilbey et al. (2011) was used to generate the annual tunnel temperature distribution as shown in Figure 3-right, varying between $15^{\circ} \mathrm{C}$ and $28^{\circ} \mathrm{C}$. The outside temperature was taken from London Weather Centre (Lincoln's Inn) at latitude 51.5 and longitude -0.117 for the year 2005 (https://www.meteonorm.com/).
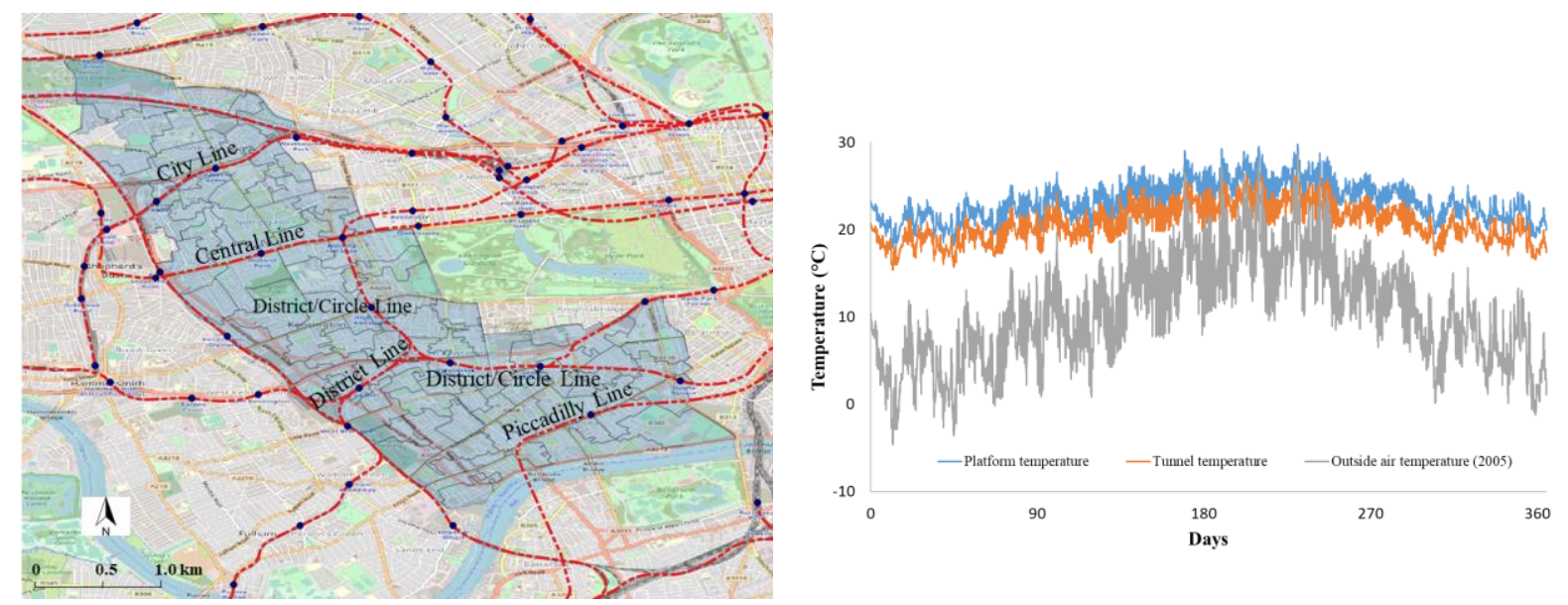

Figure 3. RBKC: left-underground rail network (RBKC, 2004), right-annual temperature distributions of platforms, tunnels and outside air.

\section{Geology and hydrogeology}

Detailed local subsurface geology and hydrogeology data of RBKC are derived from a 3D geological and groundwater model of the permeable superficial deposits (River Terrace Deposits - up to 10m thickness). Developed by the British Geological Survey (BGS), the 3D geological model is based on the 3D geo-landuse layer, which is a modified version of the 3D shrink-Swell clays dataset spanning the surface to the top of the Chalk Group (Jones et al., 2017). For our particular application, however, the geological layers to the depth of London Clay Formation are relevant as the thermal impact of subsurface structures (within RBKC) is largely limited to this depth (60-100 below the ground surface). Figure 4-a shows the 3D geological model of RBKC. In this model, each grid cell $(50 \mathrm{~m} \times 50 \mathrm{~m})$ contains several characteristics of the ground such as geological units, ground elevation, groundwater level, hydro-thermal properties, etc. The entire borough consists of about 6,000 grid cells. As the geology of RBKC is relatively consistent and varies essentially between River Terrace Deposits and London Clay Formation, the attributes of the $50 \mathrm{~m} \times 50 \mathrm{~m}$ cells of the original 3D geological model are merged 
to its $\mathrm{LSOA}^{1}$ subdivisions. By analyzing the geological variations within each LSOA at different depths, one dominant geology was selected for each LSOA at a certain depth. Figure 4-b shows a summary of the most dominant geological units per LSOA varying by depth, which is consistent with the original $50 \mathrm{~m} \times 50 \mathrm{~m}$ model.
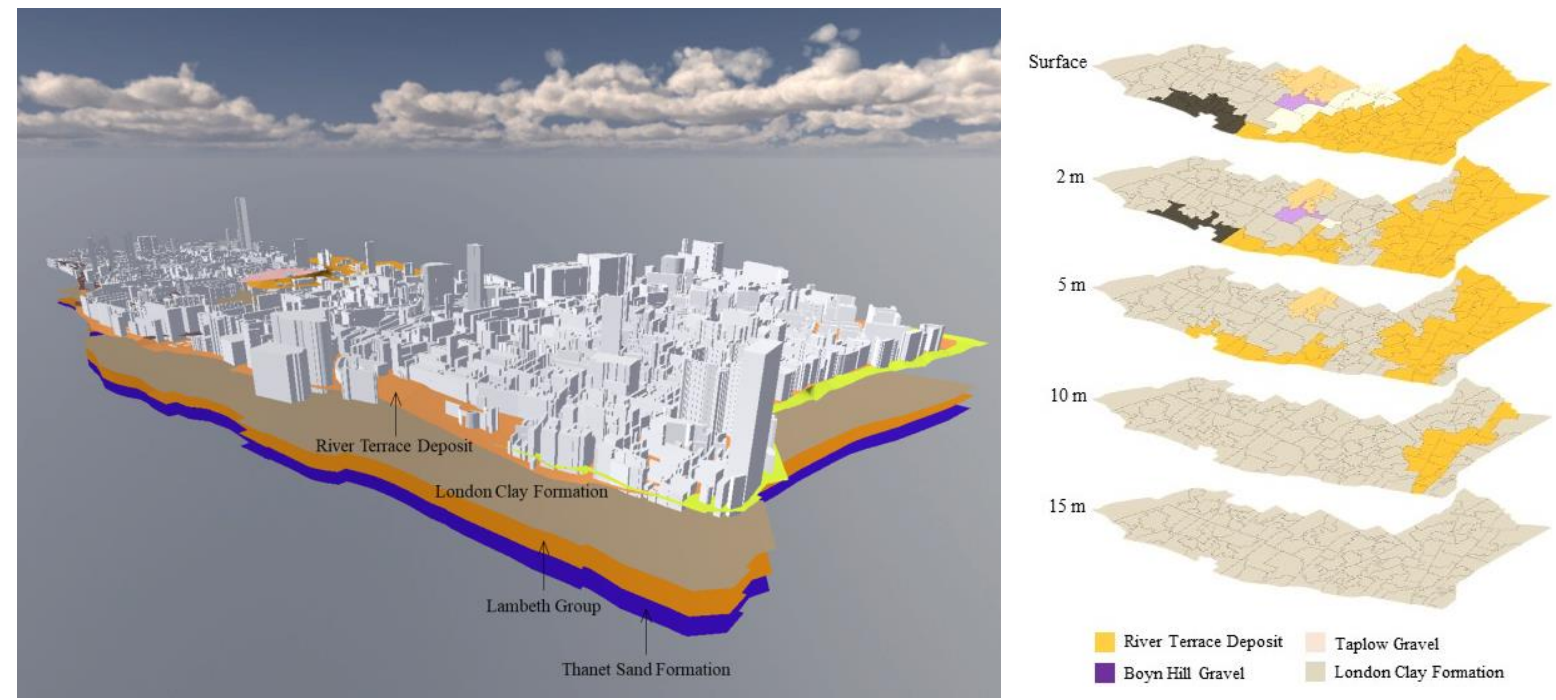

Figure 4. RBKC: a) 3D Geological model, b) geological classification at LSOA level for RBKC (not to scale).

In the 3D geological model, the ground thermal properties for different geological units (mostly gathered from Thermal Response Testing results around the UK) are spatially integrated into the model (Price et al., 2018, British Geological Survey, 2017, Busby et al., 2009). The estimated values of thermal conductivity and diffusivity for River Terrace Deposits and London Clay Formation are shown in Table 1. For the hydraulic conductivity (also listed in Table 1), BGS uses a conceptual model across the Thames Basin to define different lithostratigraphic classes of superficial deposits including River Terrace Deposits. The hydraulic conductivity of the superficial deposits is estimated from grain-size distribution data, originally collected for mineral resource assessments, using the Kozeny-Carman method (Burke et al., 2014). A relatively low hydraulic conductivity $\left(1 \times 10^{-9} \mathrm{~m} / \mathrm{s}\right)$ was assumed for the impermeable London Clay Formation.

\footnotetext{
${ }^{1}$ Lower Layer Super Output Areas (LSOAs) are a geographic hierarchy designed to improve the reporting of small area statistics in England and Wales and are generated to be as consistent in population size as possible. The Minimum population is 1000 and the mean is 1500 .
} 
The groundwater table varies between $32 \mathrm{~m}$ above sea level (northern parts of the borough) and within sea level (southern

part-River

Thames)

as

shown

in
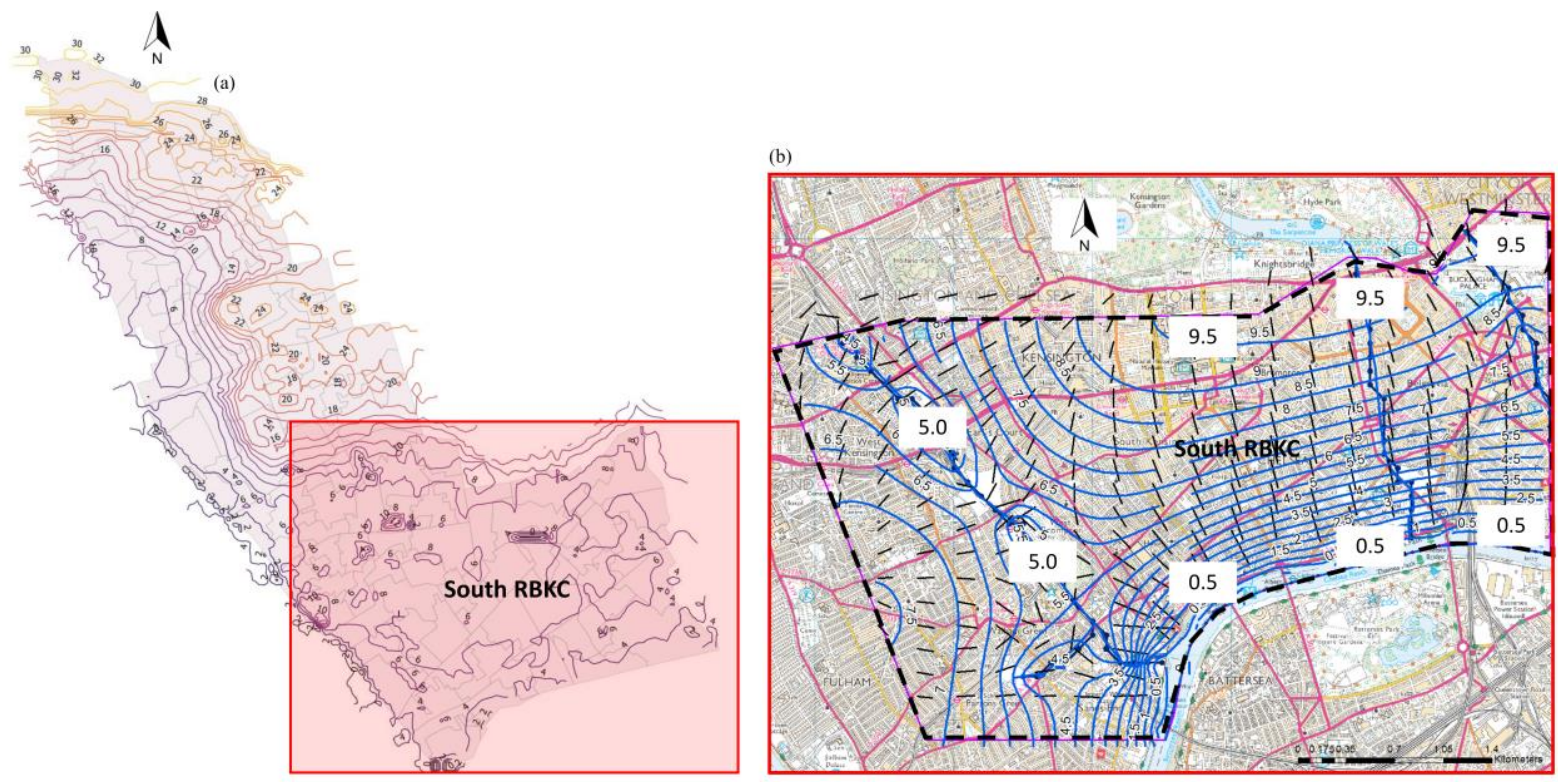

Figure 5-a. With regards to the basements and considering the depth of deepest train lines in the borough, the upper aquifer (within the superficial deposit between the ground surface and the impervious London Clay Formation) would be the relevant aquifer. Based on the shallow groundwater levels and by taking into account the lost rivers of Fleet and Westbourne and the River Thames (with an average recharge rate of $0.12 \mathrm{~m} / \mathrm{day}$ ), the relevant hydraulic heads were obtained
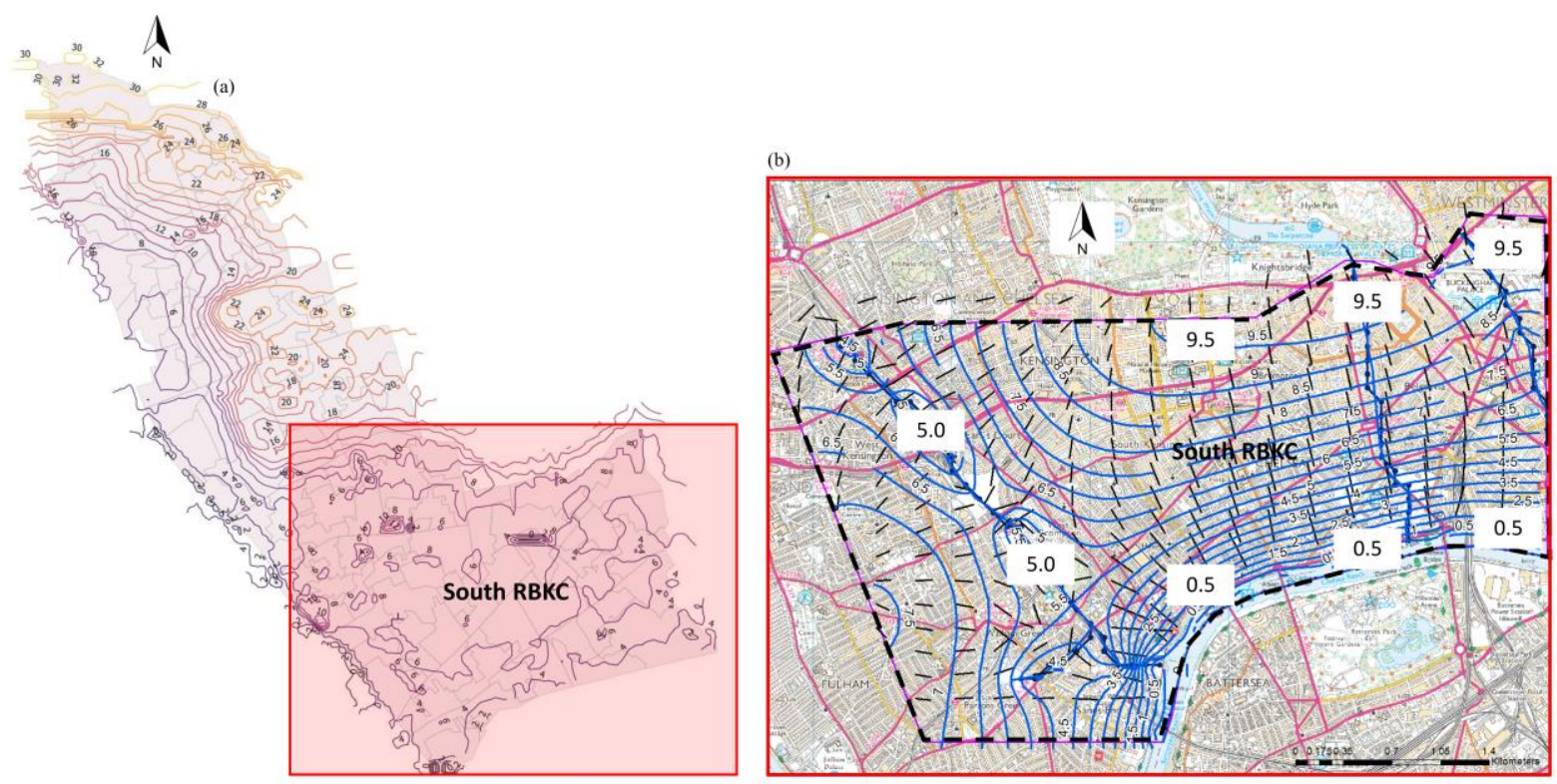

Figure 5-b).

Table 1. Hydro-thermal properties of the ground (RBKC).

\begin{tabular}{ccccc}
\hline Geology & & $\lambda[\mathrm{W} /(\mathrm{mK})]$ & $\alpha\left[\mathrm{m}^{2} / \mathrm{s}\right]$ & \multicolumn{1}{c}{$\mathrm{k}_{\mathrm{h}}[\mathrm{m} / \mathrm{s}]$} \\
\hline River Terrace Deposits (Kempton Park Gravel) & Unsaturated & 0.77 & $4.5 \times 10^{-7}$ & $4.2 \times 10^{-5}$ \\
River Terrace Deposits (Kempton Park Gravel) & Saturated & 2.5 & $9.1 \times 10^{-7}$ & $5.6 \times 10^{-4}$
\end{tabular}




\begin{tabular}{ccccc} 
London Clay Formation & Saturated & 1.79 & $9.7 \times 10^{-7}$ & $1 \times 10^{-9}$ \\
\hline
\end{tabular}

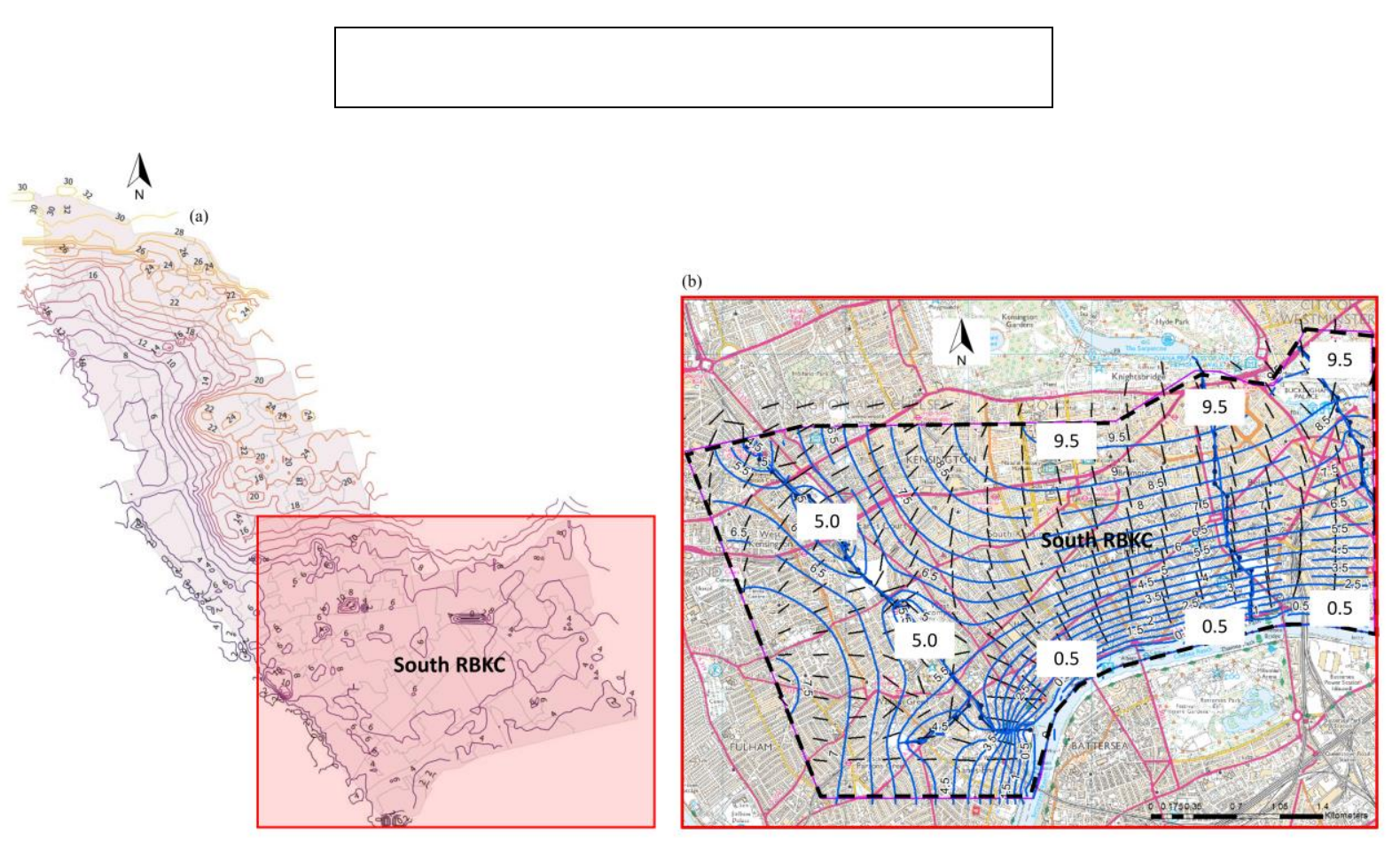

Figure 5. RBKC a) groundwater level (relative to Ordnance Datum), b) estimated groundwater hydraulic heads.Numerical modelling approach.

The core challenges in modelling ground temperatures at large scales are the size and the computational expense. Indeed, in addition to the large lateral scale, the model must account for transient thermal interactions between the ground, surface, underground structures, and groundwater variations. Considering the large lateral scale (many $\mathrm{kms}$ ) compared to the vertical scale (maximum of $100 \mathrm{~m}$ ), we propose a novel semi 3D modelling approach, in which the entire volume of RBKC is divided into several 2D horizontal planes. This model accounts for conductive and convective heat transfer and fluid flow at each plane (XY) as well as thermal interaction between different planes in the $\mathrm{Z}$ direction.

\subsection{Model set-up}

The Royal Borough of Kensington and Chelsea is divided into several 2D horizontal planes from the ground surface to $60 \mathrm{~m}$ below sea level (undisturbed ground depth). Vertical distances of $1-2 \mathrm{~m}$ are considered between the planes. In order to simulate the thermal interaction between basements and train tunnels, their spatial proximity relevant to land elevation needed to be considered. This includes: 1) the XY coordinates of basements and train lines at each plane, which was well captured in the 2D planes, and 2) the vertical distances between these structures. However, the inclusion of the exact land elevation distribution of RBKC (as shown in Figure 6-a) into these sets of 2D planes is not feasible. Thus, several average elevation distributions were used (as shown in Figure 6-b). Within the northern part of the borough, the ground surface was assumed to be $28 \mathrm{~m}$ above sea level (the highest region) and $14 \mathrm{~m}$ and $8 \mathrm{~m}$ above sea level at some parts. The ground surface is set at $8 \mathrm{~m}$ above sea level in the southern part of the borough. Figure 6-c presents the land elevations along sections A-A and B-B (shown in Figure 6-a), compared to the elevations used in numerical simulations. 

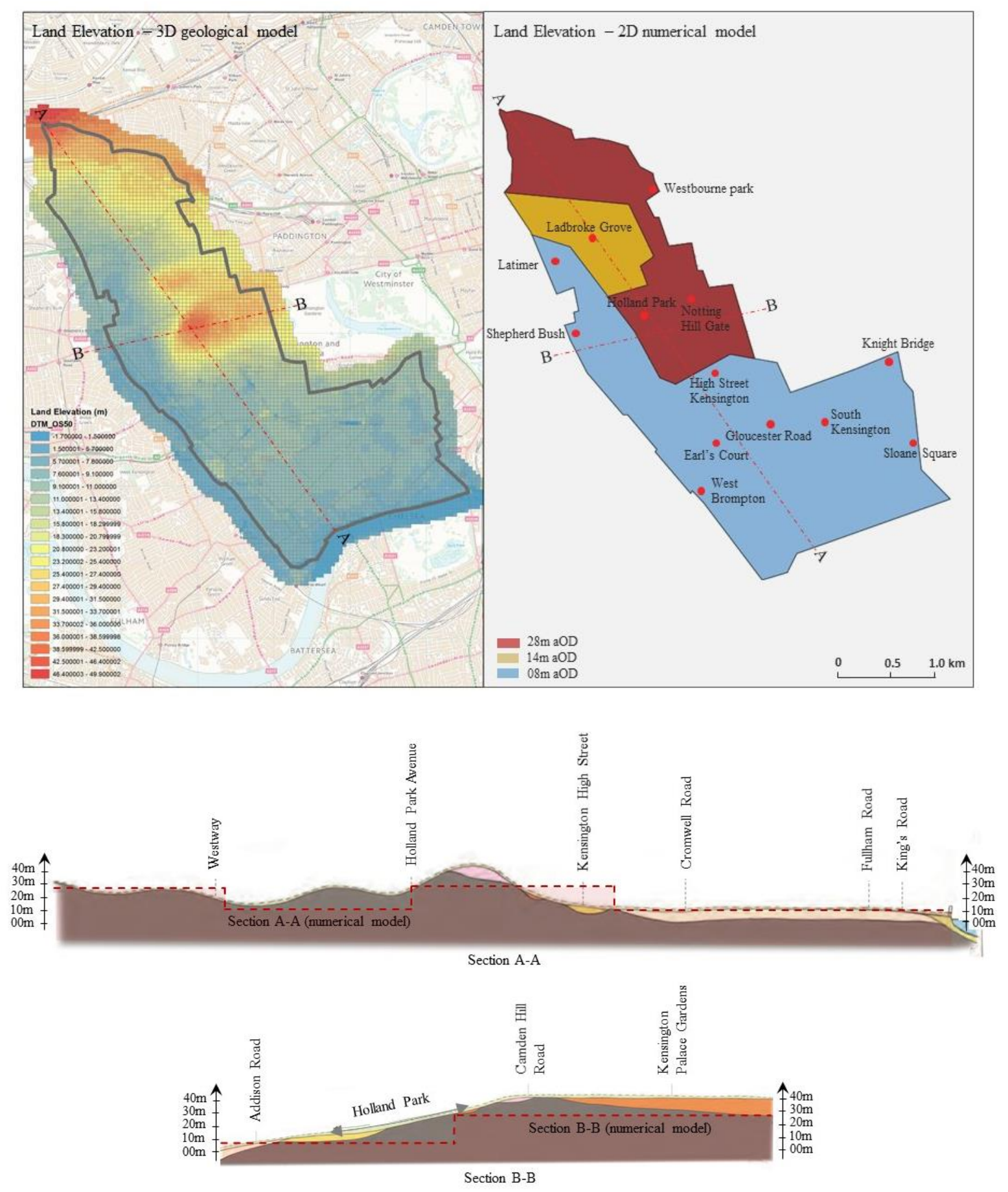

Figure 6. RBKC land elevation: a) extracted from the 3D geological model, b) used in the FE model, c) North-South and West-East land elevations.

As aforementioned, the 2D planes represent depths varying between the ground surface and the undisturbed ground ( $\sim 60 \mathrm{~m}$ below sea level). Figure 7-a shows a typical 2D plane with $1,400,000 \mathrm{~m}^{2}$ of basement floor area and about $15 \mathrm{~km}$ of train lines in RBKC. Each plane consists of about 200,000 triangular elements. Basements and train lines are activated in the relevant planes, based on their depth. Basements are activated in planes from the surface to $3 \mathrm{~m}$ below the ground surface. The depth of the stations is shown in Table 2. The tunnel depth between any two stations is assumed to vary between the depths of the two end-stations. In order to account for tunnel slope, the length of the tunnel between any two stations is divided into several sub-sections based on the depth between the two stations. Figure 8 shows an example of a tunnel representation between 2 stations (station 1 and 
2) with tunnel maximum depth of $12 \mathrm{~m}$ and plane intervals of $2 \mathrm{~m}$. The entire section length between the 2 stations, is thus divided into 7 sub-sections ((tunnel depth/plane interval)+1). Each sub-section is then presented in 3 consecutive planes. The two end sections represent the starting (shallowest) and the ending (deepest) depths of the tunnel. It should be noted that the tunnel diameter is assumed to be $4 \mathrm{~m}$.

Table 2. RBKC Station depth relevant to sea level and ground level (Transport for London, 2018)

\begin{tabular}{lccc}
\hline Station name & $\begin{array}{c}\text { Ground } \\
\text { elevation above } \\
\text { sea level }\end{array}$ & $\begin{array}{c}\text { Station depth } \\
\text { above/below sea } \\
\text { level }\end{array}$ & $\begin{array}{c}\text { Station depth } \\
\text { below ground } \\
\text { level }\end{array}$ \\
\hline Notting Hill Gate & 28 & 9.6 & -18.4 \\
Westbourne Park & 28 & 22.5 & -5.5 \\
Ladbroke Grove & 14 & 19.4 & 5.4 \\
High Street Kensington & 9 & 7.3 & -5.7 \\
Knightsbridge & 9 & -13.3 & -22.3 \\
Earls Court & 8 & -5.2 & -13.2 \\
Holland Park & 8 & -4.8 & -12.8 \\
Latimer Road & 8 & 14.0 & 6.0 \\
Gloucester Road & 7 & -6.3 & -13.3 \\
South Kensington & 7 & -6.9 & -13.9 \\
West Brompton & 7 & 2.0 & -5.0 \\
Shepherd's Bush & 6 & -10.2 & -16.2 \\
Sloane Square & 6 & -2.4 & -8.4 \\
\hline
\end{tabular}

The geological variations shown in Figure 4 are implemented into the model following the distribution presented in Figure 7-b. Based on the thickness of the permeable River Terrace Deposits, which varies between $2 \mathrm{~m}$ to $10 \mathrm{~m}$, the entire borough was divided into four geological groups. Depending on the depth that each 2D plane represents, its geological distribution would vary following the thickness of the permeable layer overlain the London Clay Formation. Combination of River Terrace Deposits and London Clay Formation was considered for planes within the first $10 \mathrm{~m}$ below the surface. Deeper than $10 \mathrm{~m}$ below the ground surface, the entire plane (representing the borough ground at a certain depth) represented the impervious London Clay Formation.

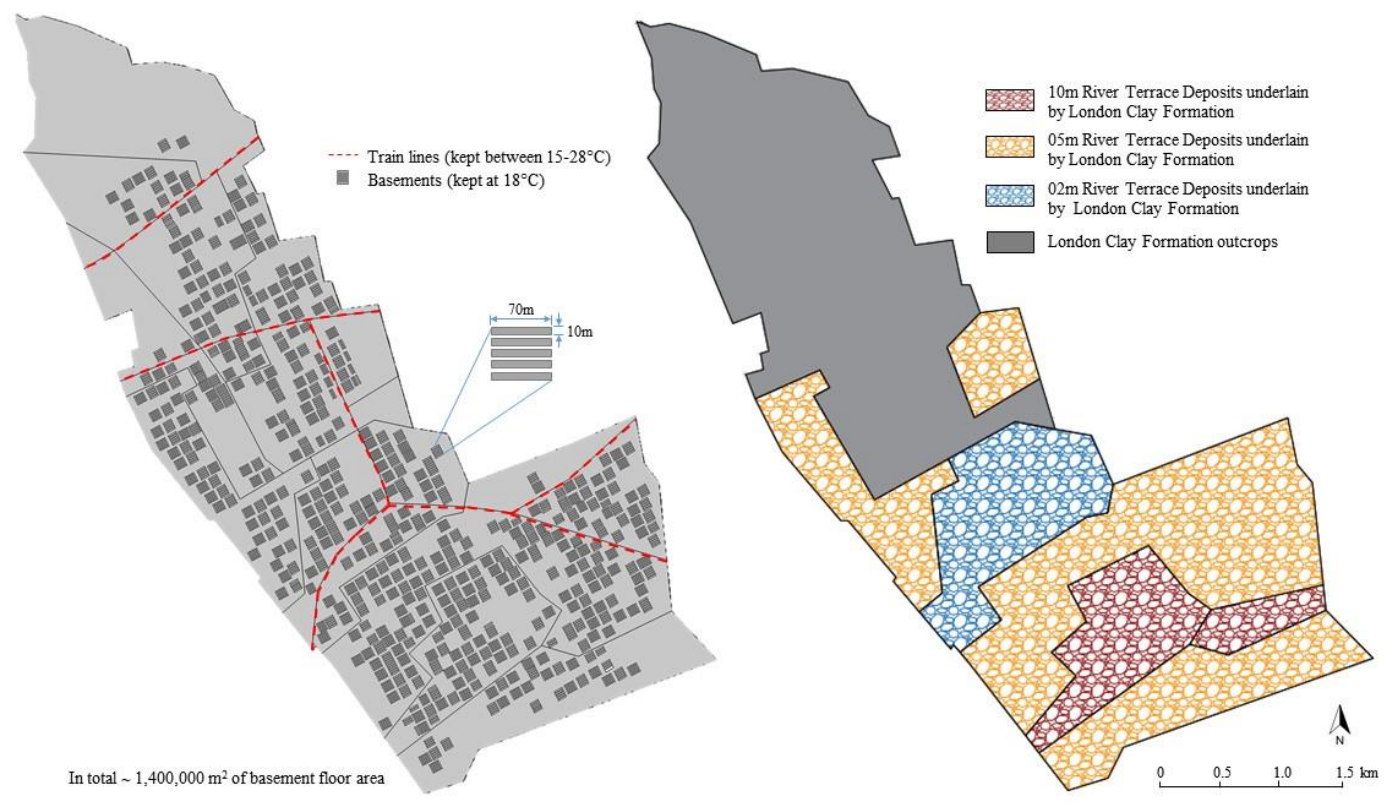

Figure 7. RBKC: a) a 2D plane representing basements and train lines, b) geological distribution - by depth - used in the numerical modelling. 


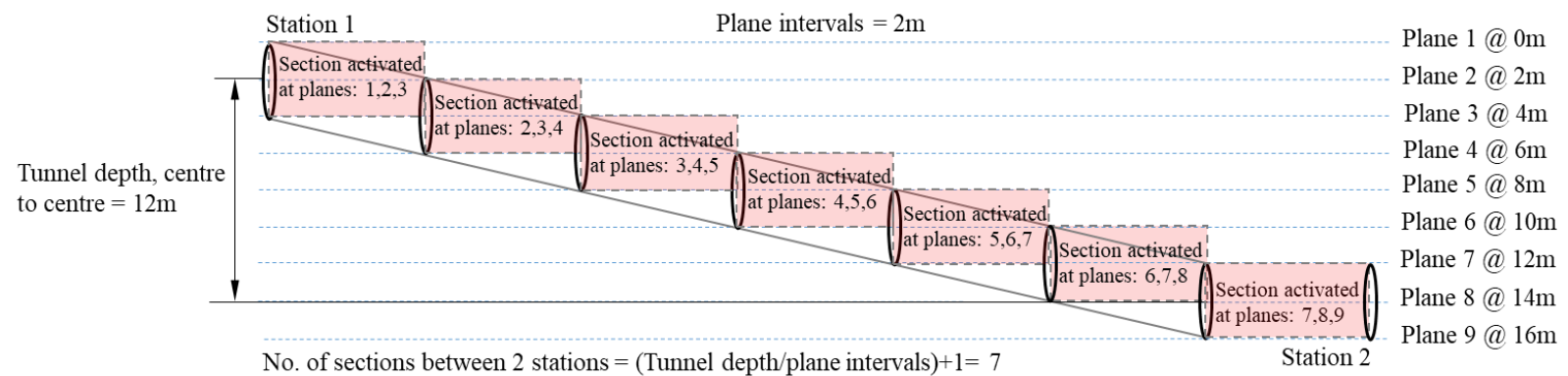

Figure 8. Schematic of the methodology used for inclusion of tunnels and their inclination in the semi 3D model.

\subsection{Governing equations, initial and boundary conditions}

Heat transfer between the basements, train lines and the surrounding ground at each 2D plane was captured by coupling and solving the equations for conductive and convective heat transfer and fluid flow in a porous medium (ground) with groundwater flow. The 2D conductive-convective heat transfer equations at each plane can be expressed as follows:

$$
\begin{array}{lr}
d_{z}(\rho C p)_{e f f} v \cdot \nabla T+\nabla \cdot q=q_{0, u p}+q_{0, \text { down }} & 1 \\
q_{0, \text { up }}=\lambda_{\text {eff }}\left(T_{n-1}-T_{n}\right) / d z \text { and } q_{0, \text { down }}=\lambda_{\text {eff }}\left(T_{n+1}-T_{n}\right) / d z & 2 \\
q=-d_{z} \lambda_{e f f} \nabla T & 3 \\
\lambda_{\text {eff }}=(1-\varepsilon) \lambda_{m}+\varepsilon \lambda_{f} & 4
\end{array}
$$

where $\mathrm{d}_{\mathrm{z}}$ is the distance between the planes (domain thickness), $\left(\rho C_{p}\right)_{\text {eff }}$ is the effective density and effective heat capacity of the porous ground, $v$ is the Darcy velocity field, $\lambda_{\text {eff }}$ is the effective thermal conductivity of the porous ground following Eq. 4 and $\varepsilon$ is the porosity. $q_{0, u p}$ and $q_{0, \text { down }}$ are the upside and downside out of plane heat fluxes, which are used to account for heat transfer in $\mathrm{Z}$ direction (between the planes $n, n-1$ and $n+1$ ) based on the effective thermal conductivity between the planes and their temperature differences.

Single phase fluid flow in a porous medium (groundwater flow) is usually described by Darcy's law, which states that the Darcy velocity field, $\boldsymbol{v}$, is determined by the total head gradient $\nabla\left(p_{f}-\rho_{f} \boldsymbol{g} z\right)$, the fluid dynamic viscosity, $\mu_{f}$, and the structure of the soil:

$$
v=-\frac{K}{\mu_{f}} \nabla\left(p_{f}-\rho_{f} g z\right) \quad \text { and } \quad \frac{K}{\mu_{f}}=\frac{k_{h}}{\rho_{f} g}
$$

where $K$ is the isotropic permeability of the ground, $p_{f}$ represents the pore pressure in the ground, $\rho_{f}$ is the groundwater density, $k_{h}$ is the hydraulic conductivity of the ground, $\mathbf{g}$ is the gravitational acceleration vector, and $\mu_{f}$ is the groundwater dynamic viscosity.

Inserting Darcy's Law into the continuity equations produces the generalized governing equation:

$$
\frac{\partial}{\partial t}(\varepsilon \rho)+\nabla \cdot \rho\left[-\frac{K}{\mu_{f}} \nabla\left(p_{f}-\rho_{f} g z\right)\right]=0
$$

Eqs. 5 and 6 are solved for $\boldsymbol{v}$ and $p_{f}$ in the ground and are coupled to Eq. 1 via $\boldsymbol{v}$.

To solve the above system of equations, appropriate initial and boundary conditions are required and summarized as follows:

- The existing groundwater flow rate and direction in southern part of the borough (where permeable superficial deposits exist) are modelled by assigning the relevant hydraulic heads to each plane. As shown 
in
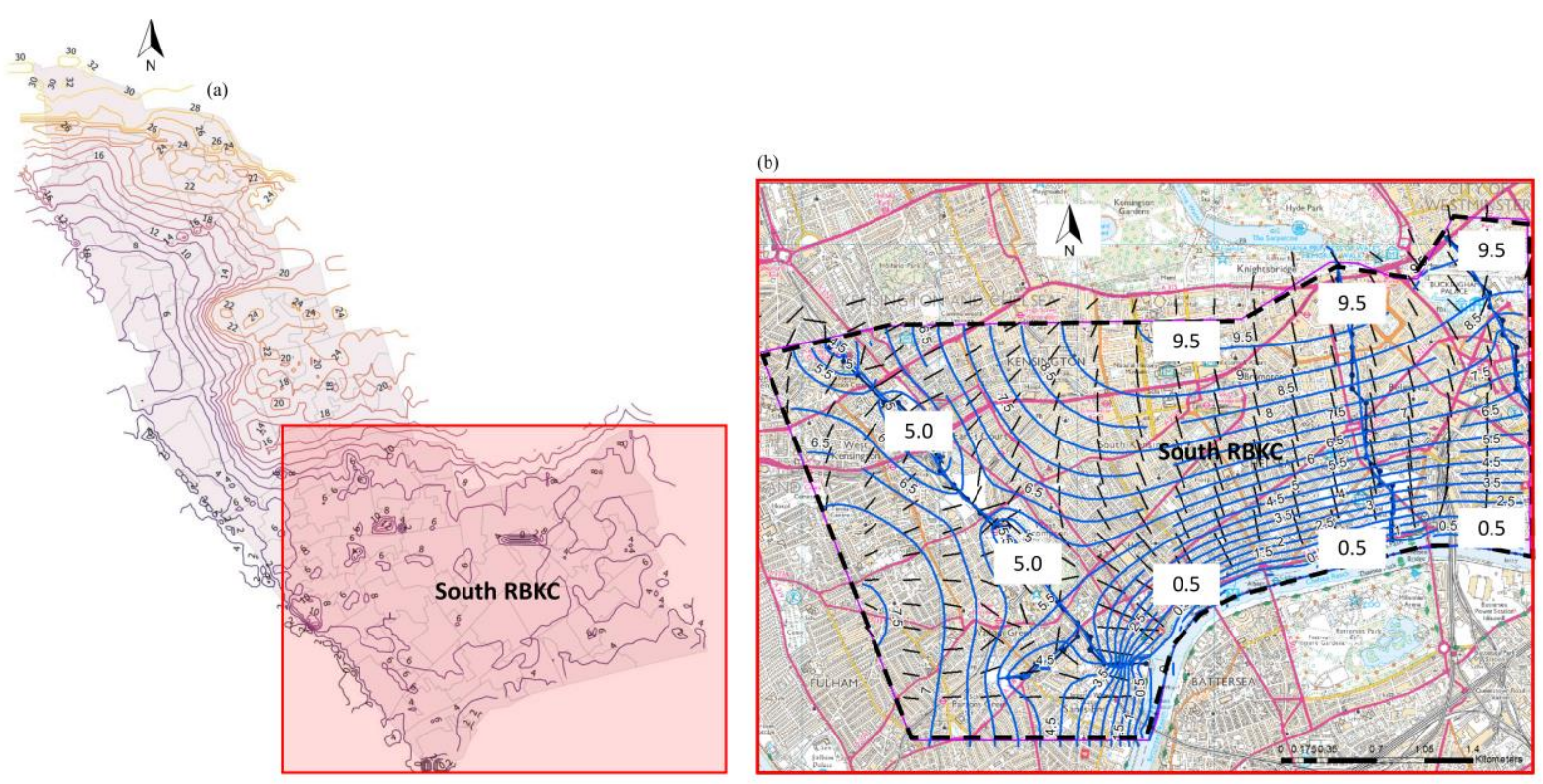

- Figure 5, the maximum head difference (relevant to OD) is around $10 \mathrm{~m}$ for the east boundary and $5 \mathrm{~m}$ for the west boundary of each plane within the first $10 \mathrm{~m}$ below ground level.

- The basements are kept at the average indoor temperature in the UK $\left(18^{\circ} \mathrm{C}\right)$ throughout the year (Lane, 2011).

- Train line temperatures follow the annual distribution shown in Figure 3 and vary between $15^{\circ} \mathrm{C}-28^{\circ} \mathrm{C}$ (Gilbey et al., 2011)

- The undisturbed ground temperature was set at $12.5^{\circ} \mathrm{C}$ based on temperature monitoring at Earls's Court, London (Price et al., 2018).

- The outer boundary of the planes are set as symmetry assuming similar thermal effects within the neighbouring boroughs from basements and train lines.

- The effect of ground surface temperature is captured within the immediate plane below ground surface (the plane $1 \mathrm{~m}$ below the surface) as a time-varying temperature via out of plane heat flux equations $\left(q_{0, u p}\right.$ as stated in Eq.2), where $T_{n-1}=T_{\text {ground }}(z=0, t)$. This temperature is applied as a time-varying temperature to the ground surface to account for surface temperature fluctuations (Baggs, 1983):

$$
\begin{aligned}
& T_{\text {ground }}(z=0, t)=T_{\text {ground,mean }}-\left(1.07 \cdot k_{v} \cdot A_{s} \times \exp \left(-0.000031552 \cdot(z=0) \cdot \alpha^{0.5}\right) \times \cos \left(\frac{2 \pi}{365}\right) \cdot(t-\right. \\
& \left.t_{0}+0.018335 .(z=0) \cdot \alpha^{0.5}\right)
\end{aligned}
$$

where $T_{\text {ground,mean }}$ is the ground annual average temperature, $\left(12.5^{\circ} \mathrm{C}\right) . k_{v}$ is the vegetation coefficient set at 0.8 accounting for an average of $30 \%$ vegetation cover. $A_{s}, 8.3^{\circ} \mathrm{C}$, is the annual air swing temperature. $t$ is the day of the year. $z$ indicates the depth in the ground and equal to 0 for the ground surface $[\mathrm{m}] . \alpha$ is the ground diffusivity equal to an average value of $9.65 \times 10^{-7} \mathrm{~m}^{2} / \mathrm{s}$, calculated based on physical and thermal properties of the soil presented in Table 2. $t_{0}$ is the coldest temperature day from January $1^{\text {st }}$ (Price et al., 2018, British Geological Survey, 2017).

\subsection{Validation of the semi 3D finite element model}

The proposed semi 3D finite element modelling approach is validated by comparing its results against a high fidelity full 3D finite element model. The full 3D model has been validated against several sets of experimental data in previous works of Bidarmaghz (2014), Bidarmaghz et al. (2017) and Makasis et al. (2018). A small-scale $(1 \mathrm{~m} \times 1 \mathrm{~m} \times 1 \mathrm{~m}) 3 \mathrm{D}$ heat transfer model was built, with three heat sources (at $\left.18^{\circ} \mathrm{C}\right)$ located at different depths and surrounded by two layers of different ground properties (Figure 9). In the 3D model, heat exchange between the heat sources and the ground is modelled using conductive heat transfer equations (Fourier's law), where the heat flux variable is evaluated based on the temperature gradient $(\nabla \mathrm{T})$ and the thermal conductivity $(\lambda)$. 
A summary of the initial and boundary conditions is shown in Figure 9 and summarized as follow:

- A constant temperature of $2^{\circ} \mathrm{C}$ is assigned to the top, bottom and one side boundary of the model.

- A constant temperature of $18^{\circ} \mathrm{C}$ is assigned to the other side boundary of the model.

- Two of the side boundaries are set as thermal insulation.

- Heat sources kept at $18^{\circ} \mathrm{C}$ are located at the depths of $0.1 \mathrm{~m}, 0.3 \mathrm{~m}$ and $0.7 \mathrm{~m}$ below the top surface of the model. The heat sources vary in length $(0.1 \mathrm{~m}$ and $0.2 \mathrm{~m})$ and are distributed non-symmetrically in the model.

- An initial temperature of $5^{\circ} \mathrm{C}$ is imposed on the entire model.

- $\quad$ The material surrounding the heat sources are consisting of two different layers as stated in Figure 9.

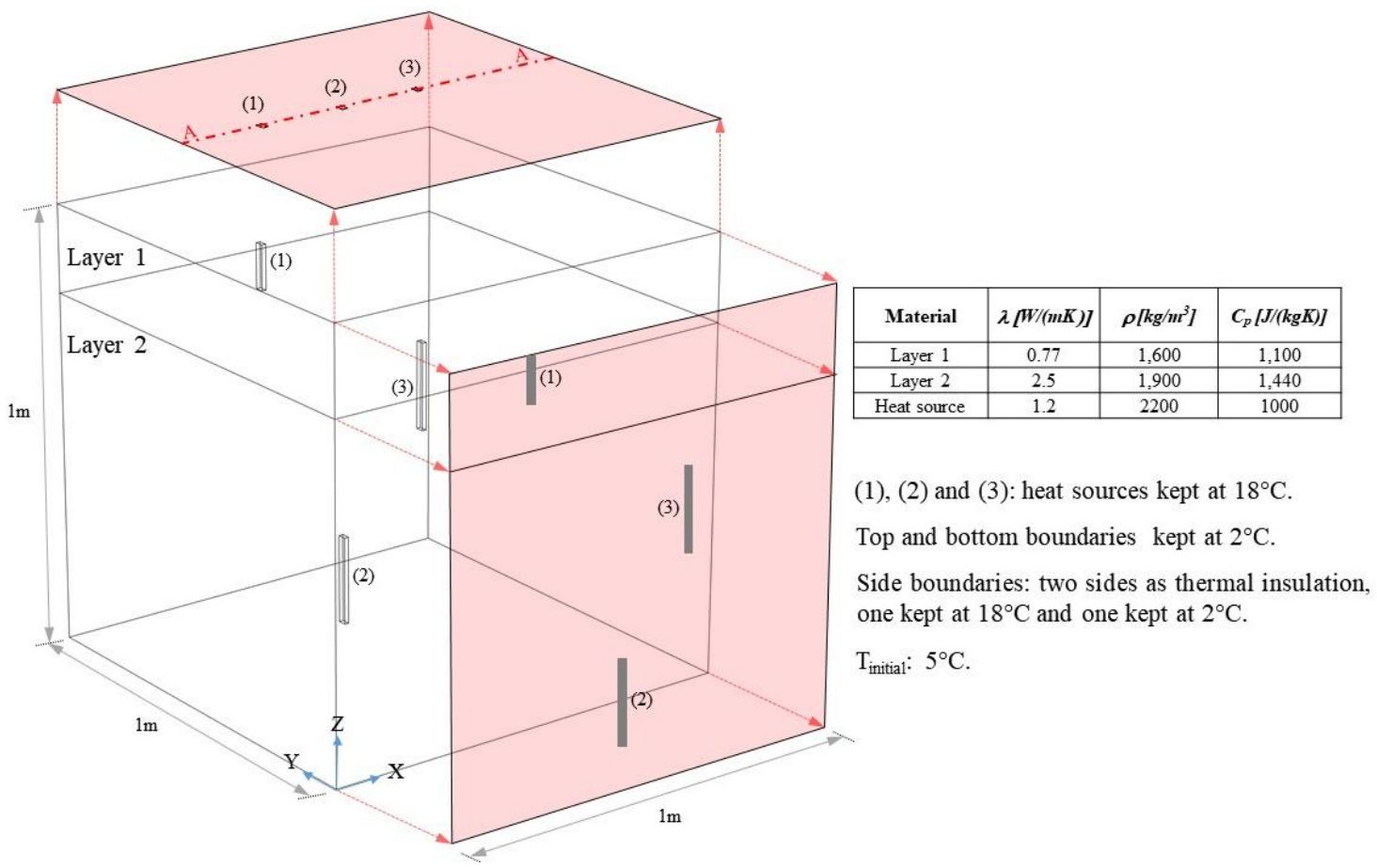

Figure 9. The geometry of the 3D finite element model used for validation.

With identical geometry and initial and boundary conditions to the 3D model, a semi 3D model was developed. This model consisted of several XY planes $(1 \mathrm{~m} \times 1 \mathrm{~m})$ for which each plane was thermally coupled to the plane above and the plane below to capture the thermal variations between the planes in the $\mathrm{Z}$ direction (depth) - in addition to the conductive heat transfer within each plane. The geometry is presented in Figure 10. Each 2D geometry consisted of three rectangular surfaces representing the horizontal cross-sections of the 3D heat sources (sources (1) to (3)) surrounded by the ground. Nine planes were modelled herein, at the depths of $0.1 \mathrm{~m}$ to $0.9 \mathrm{~m}$ (with $0.1 \mathrm{~m}$ plane intervals). Heat sources were activated/deactivated in the planes according to their depth of appearance (for example, heat source (2) is activated in the $0.3 \mathrm{~m}, 0.4 \mathrm{~m}$ and $0.5 \mathrm{~m}$ planes). The general conductive heat transfer equations used to model the heat exchange between the heat sources and the surrounding ground at each plane can be expressed as:

$$
q=-d_{z} \lambda \nabla \mathrm{T}
$$

where $d_{z}$ is the domain thickness, $\lambda$ is the thermal conductivity of material at each plane (including the ground and the heat sources) and $\nabla \mathrm{T}$ represents the temperature gradient within the plane. An out of plane heat flux is allowed on each plane to couple its temperature $\left(T_{n}\right)$ to the plane below $\left(T_{n+1}\right)$ and the plane above $\left(T_{n-1}\right)$ using Eq. 2. The top and bottom planes (kept at a constant temperature of $2^{\circ} \mathrm{C}$ in the $3 \mathrm{D}$ model) are not modelled. However, their impact was accounted using out of plane heat flux equations. A temperature difference of $\left(2^{\circ} \mathrm{C}-\mathrm{T}_{\mathrm{n}}\right)$ was considered in out of plane heat flux equations at $0.1 \mathrm{~m}$ and $0.9 \mathrm{~m}$ planes, where $T_{n}$ is the temperature distribution of the plane at $0.1 \mathrm{~m}$ and $0.9 \mathrm{~m}$ and $d_{z}=0.1 \mathrm{~m}$ (following Eq. 2). 
The additional initial and boundary conditions used at each plane are as follow:

Similar to the $3 \mathrm{D}$ model, an initial temperature of $5^{\circ} \mathrm{C}$ is assigned to the whole geometry.

Two of the sides of each plane represent thermal insulation, one side is set at $2^{\circ} \mathrm{C}$ and one side set at $18^{\circ} \mathrm{C}$ as shown in Figure 10.

Top and bottom surface were assigned a constant temperature of $2^{\circ} \mathrm{C}$. 


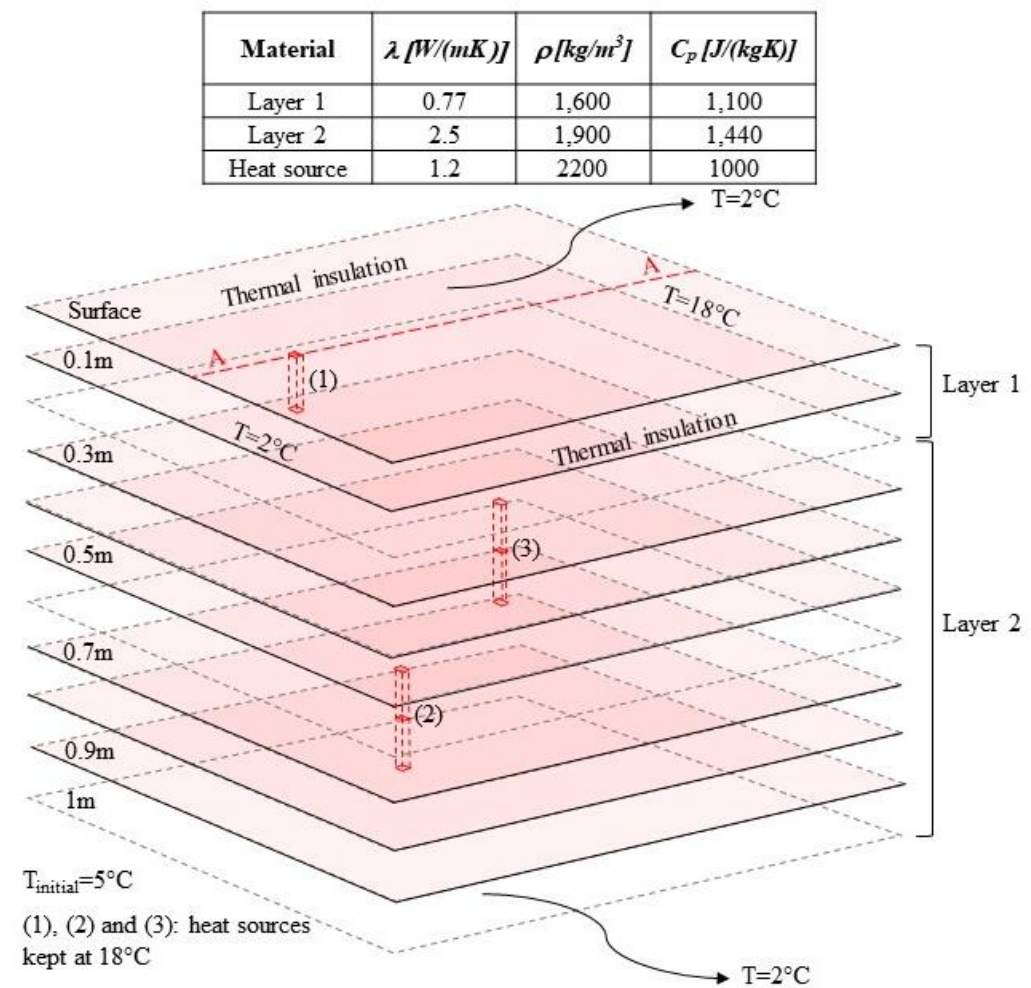

Figure 10. Schematic of the 2D planes, the initial and boundary conditions.
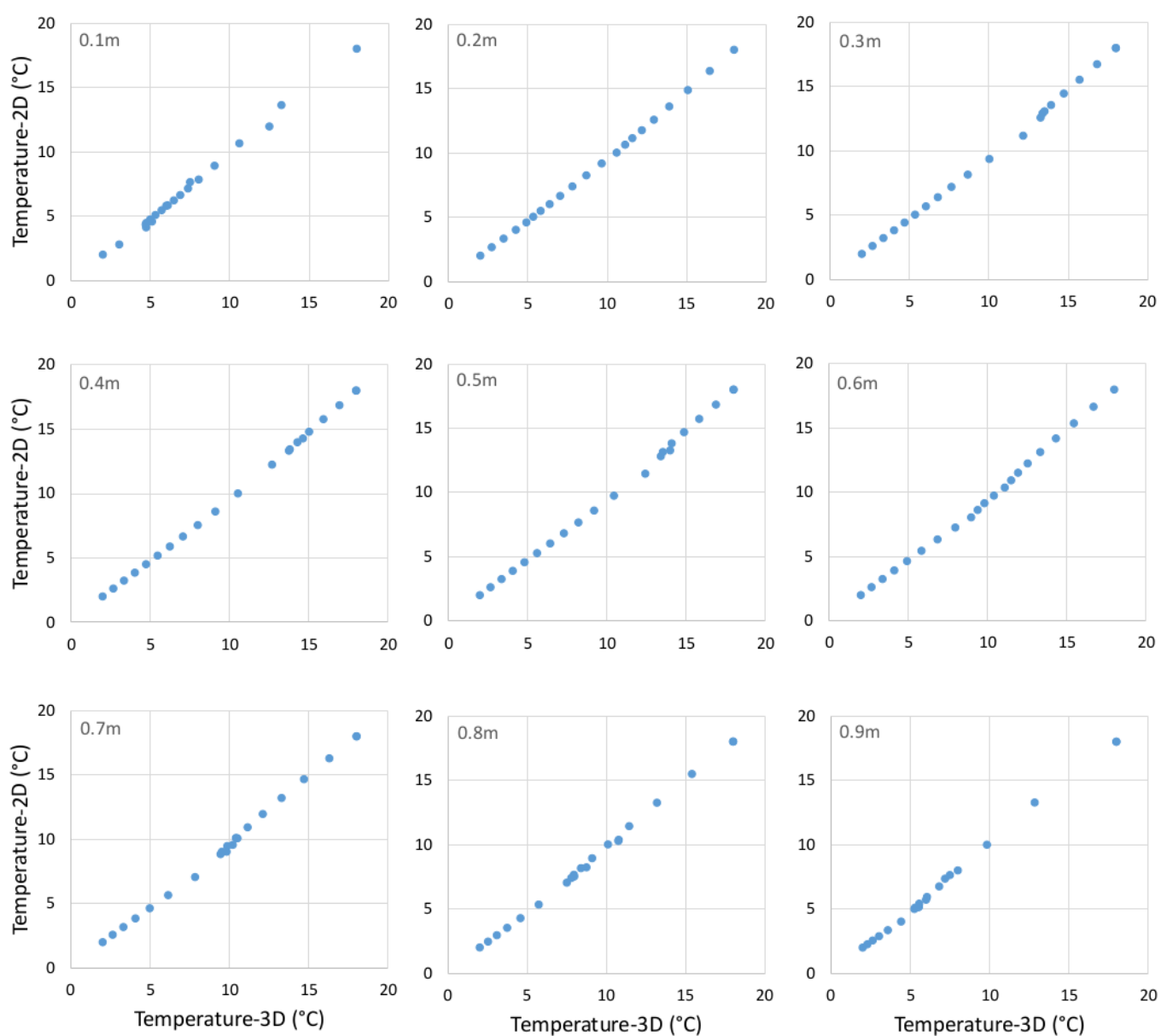

Figure 11. Comparison of 2D and 3D temperature distributions at different depths. 
The steady-state temperature distribution of the proposed and the full 3D models along the A-A line shown in Figure 9 and Figure 10 are compared. Results shown in Figure 11 confirm the accuracy of the proposed semi 3D finite element approach and its capability to capture the heat exchange between the heat sources and the ground in $\mathrm{X}, \mathrm{Y}$ and $\mathrm{Z}$ direction. Thus, this method can be considered as a reliable replacement for full 3D finite element model to tackle the size issues of our large-scale simulations.

\section{Results and discussion}

There are about 13,000 known residential basements in RBKC, for which $70 \%$ of them are constructed within $60 \%$ of the borough and within shallow subsurface comprising River Terrace Deposits (mostly southern parts). The other $30 \%$ of basements are within the remaining $40 \%$ of RBKC, within London Clay outcrops (northern parts). Therefore, for a total $12 \mathrm{~km}^{2}$ surface area of RBKC, the density of basements in southern parts is around $50 \%$ higher than the northern parts. The train lines are distributed relatively evenly within the entire borough's subsurface.

In southern parts, where shallow subsurface accommodates densely constructed basements in permeable River Terrace Deposits; an average temperate elevation of $\sim 1.5^{\circ} \mathrm{C}$ is observed within the first $70 \mathrm{~m}$ of the ground, with $7^{\circ} \mathrm{C}$ at its maximum. In the northern part, where the ground consists of impermeable London Clay Formation and the density of basements is lower, the average temperate elevation is $\sim 0.5^{\circ} \mathrm{C}$ and the maximum temperature rise is $6.2^{\circ} \mathrm{C}$. The accumulative thermal effect of $3 \mathrm{~m}$ deep heated basements is detectable to the maximum depth of $50 \mathrm{~m}$ below surface in this area. More specific results with respect to ground temperature elevations and geothermal potential are presented in the next section.

\subsection{Ground temperature distributions}

Numerical simulations were conducted for a period of 25 years with the ground surface and train line temperatures varying by time, while the basements temperature was kept at a comfortable level of $18^{\circ} \mathrm{C}$ throughout the year. The basements were located within the first $3 \mathrm{~m}$ below the surface. The train lines, however, were distributed at different depths, with shallowest at about $6 \mathrm{~m}$ below the surface (City line - Westbourne Park) and deepest at about $24 \mathrm{~m}$ below the surface (Circle line - Knight Bridge). Figure 12-a shows the spatial temperature distribution in RBKC $3 \mathrm{~m}$ below the ground surface. In this figure, all basements are visualized in one cross-sectional plane, disregarding the surface elevation variations for different areas in the borough. The average temperature rise in the northern part of RBKC at the depth of $3 \mathrm{~m}$ is numerically evaluated at about $0.6^{\circ} \mathrm{C}$, with maximum temperature increase of $6.7^{\circ} \mathrm{C}$. It must be noted that basements are within the depth of seasonal fluctuations. Undisturbed ground temperature at this depth is higher than its annual average temperature in summer $\left(15.5^{\circ} \mathrm{C}\right.$ vs $\left.12.5^{\circ} \mathrm{C}\right)$ and lower in winter $\left(9.3^{\circ} \mathrm{C}\right.$ vs $\left.12.5^{\circ} \mathrm{C}\right)$. The lateral thermal effect of heated basements in this part of RBKC is relatively insignificant. Due to the impermeable ground surrounding the basements and relatively uneven distribution of basements in this area, the majority of the ground in the northern parts remains thermally intact resulting in concentrated temperature elevations within the immediate ground surrounding these structures. Results indicate that within the first $3 \mathrm{~m}$ below surface, only around $7 \%$ of the ground is thermally affected showing an average temperature rise of $0.6^{\circ} \mathrm{C}$.

For basements constructed in River Terrace Deposit (mainly southern parts), the thermal effect of heated basements extends significantly in the direction of groundwater flow, affecting a large portion of the ground in southern parts. An average ground temperature rise of $2^{\circ} \mathrm{C}$ (Figure 12-a) is evaluated for the first $3 \mathrm{~m}$ below ground surface with its maximum value being at $8.4^{\circ} \mathrm{C}$. The high permeability of the ground and the high density and relatively even distribution of basements in the area have resulted in a significant thermal disturbance in the ground. Within the depth of basements, around $30 \%$ of the ground in south RBKC shows at least an average temperature elevation of $2^{\circ} \mathrm{C}$, indicating largely accessible geothermal energy in most parts of the area.

The depth for which the maximum length of train lines is constructed in RBKC is about $6 \mathrm{~m}$ below sea level, where deep lines such as Central, District and Circle lines are operating. Figure 12-b shows the temperature distribution at this depth. As the train lines are within London Clay Formation, their thermal impact is local and within close proximity to the tunnels. The only location where the lines are laying within permeable gravel is around High Street Kensington (dashed circle in Figure 12-b). The significant temperature elevation around High Street 
Kensington highlights the impact of train tunnels on the thermal state of the ground when constructed in permeable ground with groundwater flow. The northern and southern parts show different ground average temperatures at this depth $\left(12.8^{\circ} \mathrm{C}\right.$ vs $\left.14.1^{\circ} \mathrm{C}\right)$. This is due to the substantial effect of shallow heat sources (basements) on ground temperature at deeper depths, when shallow ground permeability is high and basements are well distributed within subsurface. Similar trend is observed at $40 \mathrm{~m}$ below sea level (Figure 12-c), with smaller temperature elevations and mostly at the southern parts.
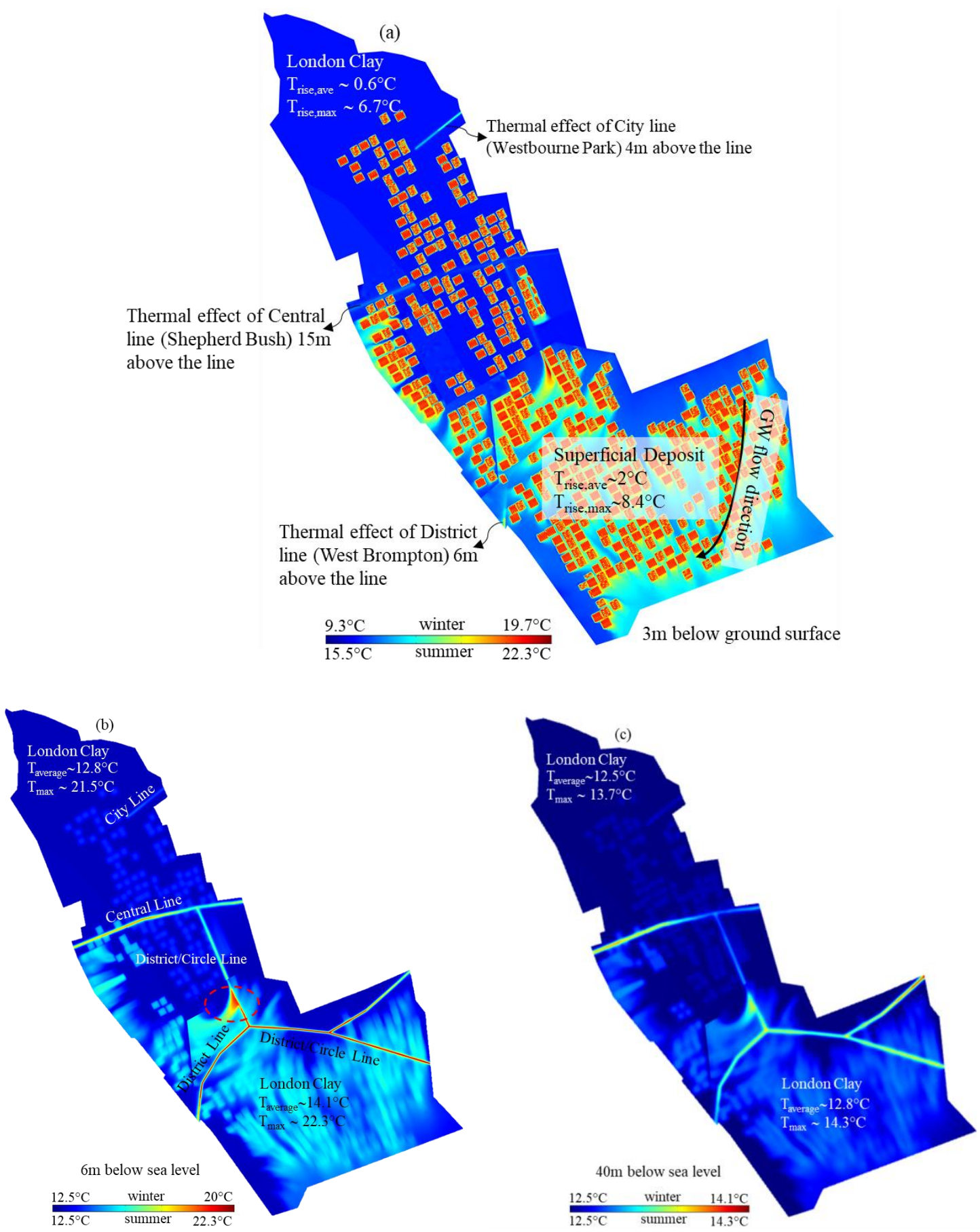

Figure 12. Spatial ground temperature distribution: a) $3 \mathrm{~m}$ below ground surface, b) $6 \mathrm{~m}$ below sea level and c) $40 \mathrm{~m}$ below sea level.

To further investigate the observations shown in Figure 12, temperatures along section A-A and B-B are evaluated at different depths and presented in Figure 13. Section A-A (Figure 13-a) is within the northern part of the borough dominantly within London Clay Formation, whereas section B-B (Figure 13-b) is in the southern part passing 
through River Terrace Deposits within the first $10 \mathrm{~m}$ below the surface. The highly fluctuating temperature along section A-A at different depths explains the locality and high concentration of temperature elevation within immediate ground surrounding the basements. Section B-B shows a significantly different spatial temperature distribution to section A-A, even though the density of basements along both section lines is similar. The horizontal extension of thermal effect is profound and significantly larger than its vertical extension along section B-B (kms vs max of $100 \mathrm{~m})$. The substantial thermal interference between shallow underground structures within line B-B has resulted in a more consistent, less fluctuating temperature elevation along this line. Within Section A-A, if basements are only slightly distanced from each other, the ground in between the basements has remained thermally intact. Whereas, ground temperature along section B-B is observed to be severely disturbed and consistently higher than the ground undisturbed temperature, unless basements are significantly further apart. Comparison between sections A-A and B-B highlights the importance of planning the distribution of underground structures across districts with consideration of ground properties. For example, heated underground structures can be located at a higher density within impermeable material (e.g., northern RBKC) to yield similar ground thermal disturbance as on permeable ground. Similar consideration applies for geothermal planning. A geothermal system extracting heat from the ground would be more efficient when located close to heat sources in northern RBKC, as against southern RBKC, where temperature elevations due to heat sources are more evenly spread.
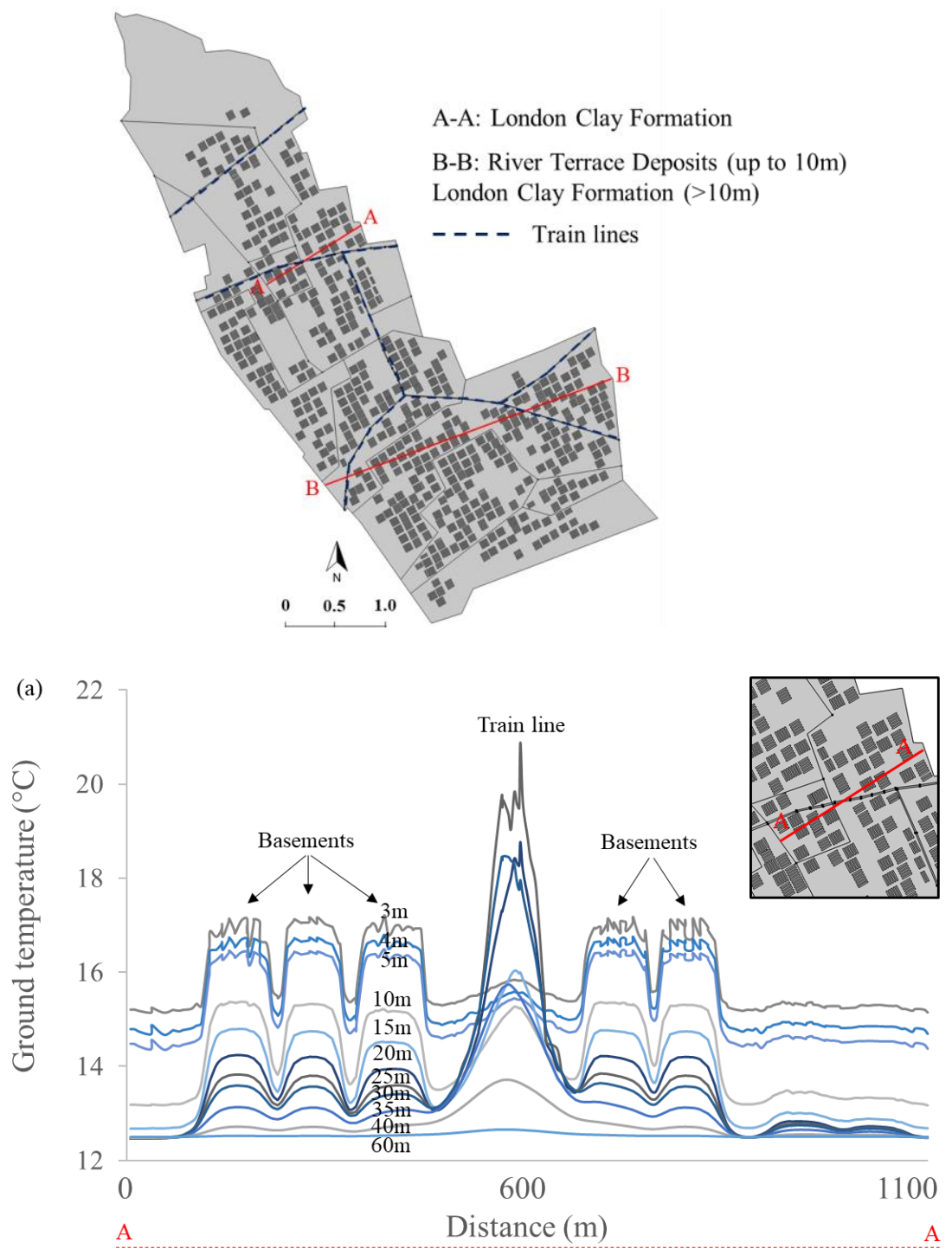


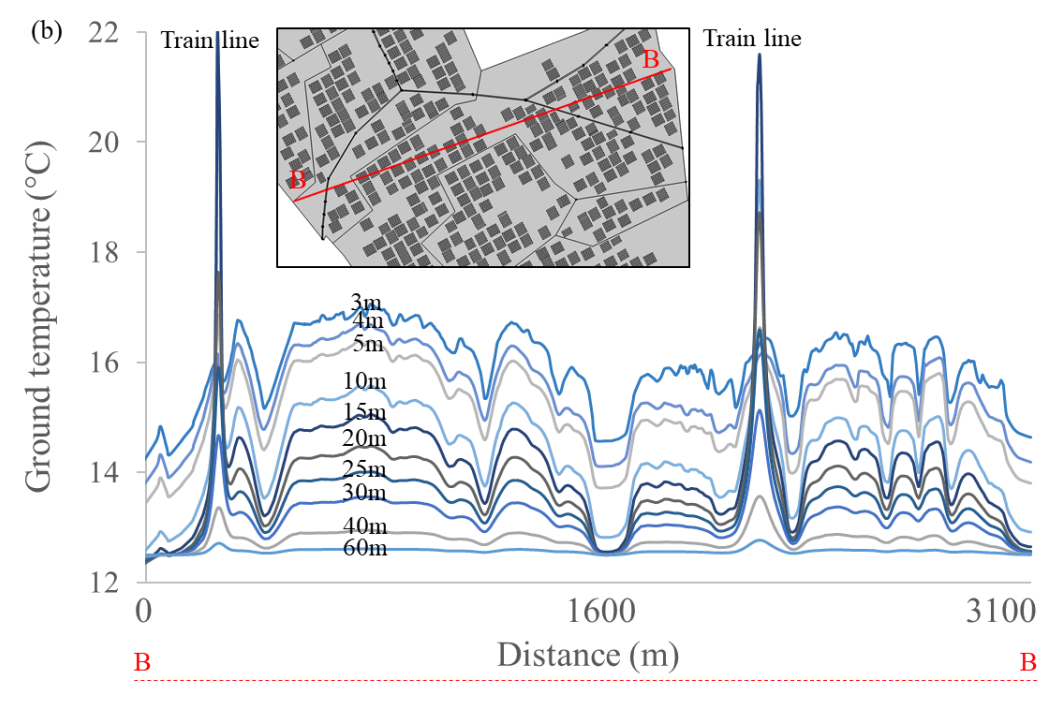

Figure 13. Cross-sectional temperature profile along: a) section A-A, b) section B-B.

The combined influence of ground properties and underground structures is evaluated considering specific points in the borough. The temperature profile at four different points in RBKS is shown in Figure 14. Points Clay-A and $\mathrm{B}$ are within northern parts of the borough, one located in an area with low basements density (Clay-A) and Clay-B is in an area with densely constructed basements. Similarly, for the other two points located in the southern parts, Gravel-A is where the number of basements is insignificant, and Gravel-B is in Earl's Court area with high density of residential basements.

The temperature gradients in the impermeable London Clay Formation (Points Clay-A and Clay-B) show a similar trend for both points but with larger geothermal deviation depth in point Clay-B $(50 \mathrm{~m}$ vs $10 \mathrm{~m})$. The thermal impact of basements constructed in London Clay dissipates quickly by depth. Therefore, despite the high density of basements in point Clay-B, a very slight temperature deviation (from ground undisturbed temperature) is observed for this point. In the permeable ground, however, the combination of geology, hydrogeology and the configurations of underground structures has resulted in higher temperature ranges and more significant temperature variations from point to point. The significant inclination of the profiles to temperatures higher than $12.5^{\circ} \mathrm{C}$ (right side of the plot) for both Gravel points indicates how basements constructed in shallow permeable subsurface with groundwater flow can influence the ground temperature at deeper depths and even at a lateral distance from underground heat sources (Gravel-A). A large temperature deviation is observed for both points in Gravel up to the depth of $70 \mathrm{~m}$ below surface, which is more significant for Gravel-B due to the high density of basements but still remarkable in Gravel-A. This highlights the wide accessibility of ground energy within southern RBKC. The temperature profile experimentally measured at Earl's Court, London (Price et al., 2018) is also presented in Figure 14 (dashed line) showing good agreement with the simulated temperature profile (point Gravel-B, Earl's Court). 


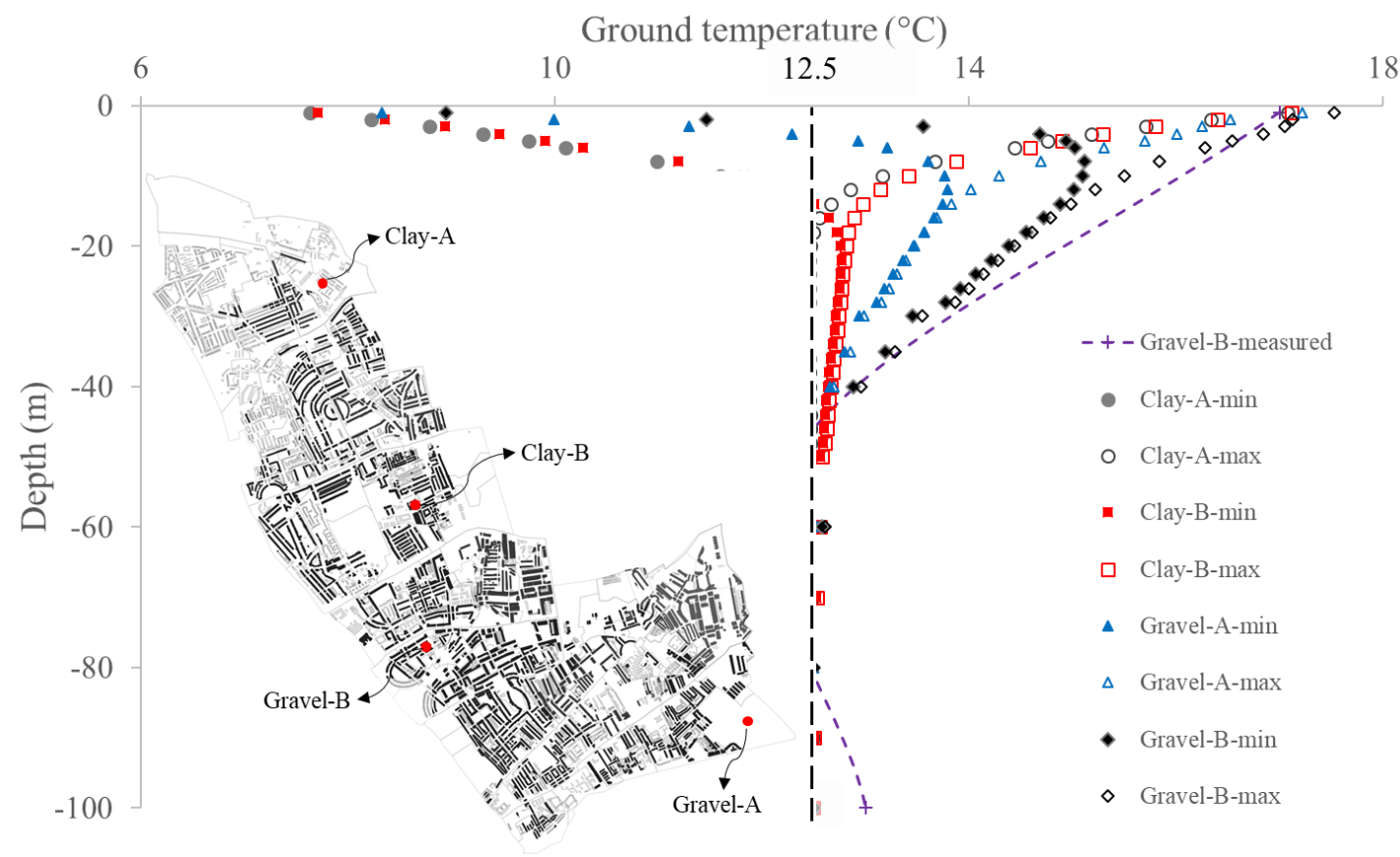

Figure 14. Measured and numerically simulated temperature profiles showing ground thermally disturbed temperature.

\subsection{Geothermal energy potential}

Considering the thermally affected volume of the ground in both northern parts and southern parts of RBKC, the geothermal potential can be substantial. The numerical results have shown an average temperature elevation of $0.5^{\circ} \mathrm{C}$ within $50 \mathrm{~m}$ below surface in the northern part of RBKC (comprising $40 \%$ of borough's area) and around $1.5^{\circ} \mathrm{C}$ for the $60 \%$ of the borough constructed on permeable River Terrace Deposits in the southern parts (up to the depth of $70 \mathrm{~m}$ below surface). In addition to the different average temperature elevations, the concentration of heated up areas in the ground is significantly different in the two areas. Considering the volume of the impermeable clay ground within 50m below surface (depth of undisturbed ground) in the northern parts of RBKC and with a minimum temperature elevation of $0.5^{\circ} \mathrm{C}$, the available geothermal energy in the area is evaluated. With $40 \%$ of residential houses $(8,800$ out of 22,000$)$ located in the northern parts (GeoInformation, 2017a) and assuming an average annual gas consumption of $12,400 \mathrm{kWh}$ per household (Statistical data set, 2017), the available energy in the ground can fulfil around $9 \%$ of the annual domestic gas consumption of the northern part. In other words, this energy can fulfil the five-year gas demand for around 170 houses (out of 8,800) in the area. As discussed before, the accumulation of heat in the northern part of RBKC is local and within immediate ground surrounding the basements. Therefore, the average $0.5^{\circ} \mathrm{C}$ temperature elevation only exists within $6 \%$ of the ground volume within $50 \mathrm{~m}$ below surface in northern RBKC.

To evaluate the geothermal energy potential available in the southern part of RBKC, the volume of ground (up to $70 \mathrm{~m}$, the depth of undisturbed ground) in the area with a minimum temperature elevation of $1.5^{\circ} \mathrm{C}$ is calculated. Assuming that $60 \%$ of RBKC's residential houses are in this area (GeoInformation, 2017a) and an average gas consumption of 12,400 kWh per household, the available ground energy within the $70 \mathrm{~m}$ below ground surface, can fulfil the total gas consumption of 3,900 houses (out of 13,200) for five years. More importantly, the evenly distributed heated up regions in the ground in south RBKC, results in larger volume of ground possessing a substantial temperature elevation, hence larger geothermal energy potential being available.

Figure 15 shows the ranges for ground temperature elevation, geothermal energy and percentage of disturbed volume of ground surrounding 1) basements and 2) train tunnels. Figure 15-a shows the minimum (summer) and maximum (winter) average temperature elevations in the ground surrounding the basements (volume of ground between surface and $3 \mathrm{~m}$ depth) in the northern and southern parts and in the ground around train tunnels at the depths where maximum length of train lines exists (volume of ground between 12 to $16 \mathrm{~m}$ below surface, within the southern parts of RBKC). Shallow subsurface is thermally influenced by the ground surface temperature 
fluctuations, hence yielding different temperature elevations in summer and winter. These seasonal variations are not observed for the deeper ground around train tunnels.

The accessible ground energy due to this temperature elevation is presented in Figure 15-b, for which the Clay ground surrounding basements shows the minimum available ground energy $(<1 \mathrm{GWh}$ for a temperature rise between $0.3^{\circ} \mathrm{C}$ and $1^{\circ} \mathrm{C}$ ). However, the relationship between ground temperature rise and ground energy appears to be non-linear. This is due to the fact that apart from temperature elevation, the volume of ground possessing this temperature elevation also needs to be evaluated. The volume of ground within the basements depth in north RBKC with noticeable temperature elevation is small and limited to the immediate ground around basements (between 4-7\% as shown in Figure 15-c), resulting in an insignificant geothermal potential in that area. As the ground within the depth of train tunnels similarly consists of impermeable London Clay Formation, similar trend with regards to the ground energy might be expected. It is observed, however, that the available geothermal energy around tunnels is significant ( $\sim 6 \mathrm{GWh}$ of energy for $\sim 1.5^{\circ} \mathrm{C}$ temperature elevation). This is due to the residual thermal impact of basements constructed in shallow permeable Gravel reaching the deeper Clay ground around train tunnels in south RBKC. Therefore, around $25 \%$ of the Clay ground at these depths is thermally disturbed, resulting in larger available ground energy. The high permeability of shallow ground around basements in south RBKC, the presence of groundwater flow and the even distribution of heated basements have led to the Gravel ground surrounding basements showing the maximum range for temperature elevations $\left(1-3.2^{\circ} \mathrm{C}\right)$. The maximum available ground energy $(6.5-13.5 \mathrm{GWh})$ with thermal disturbance within $18 \%$ to $29 \%$ of the ground is also observed for this area.

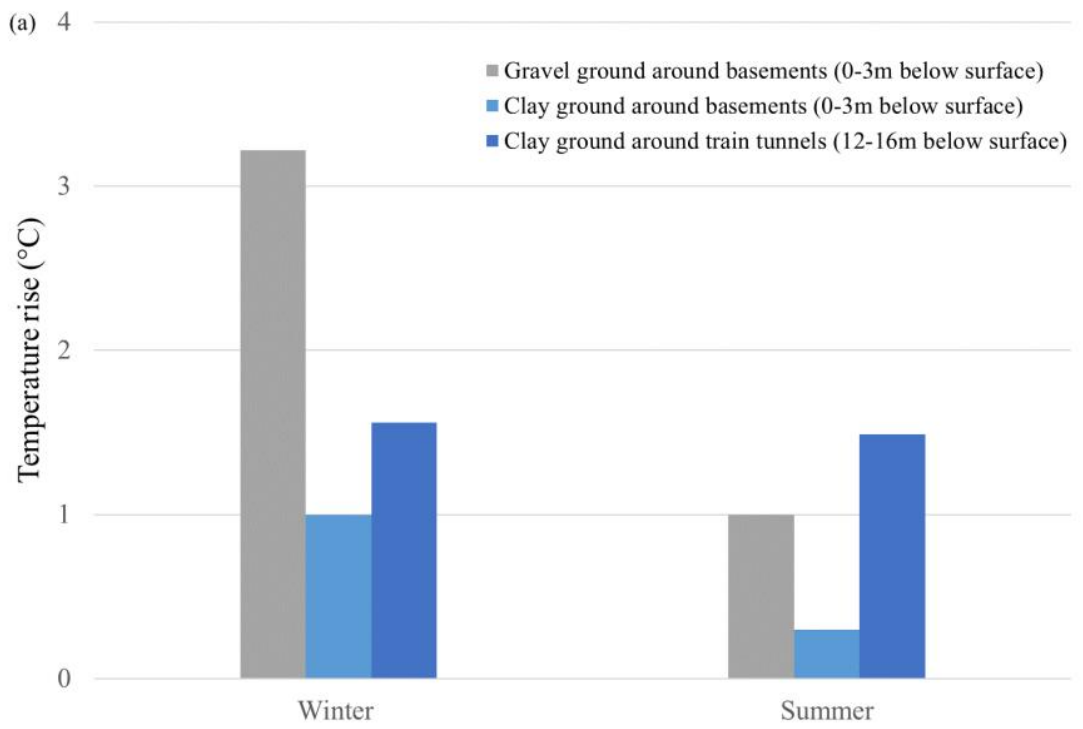



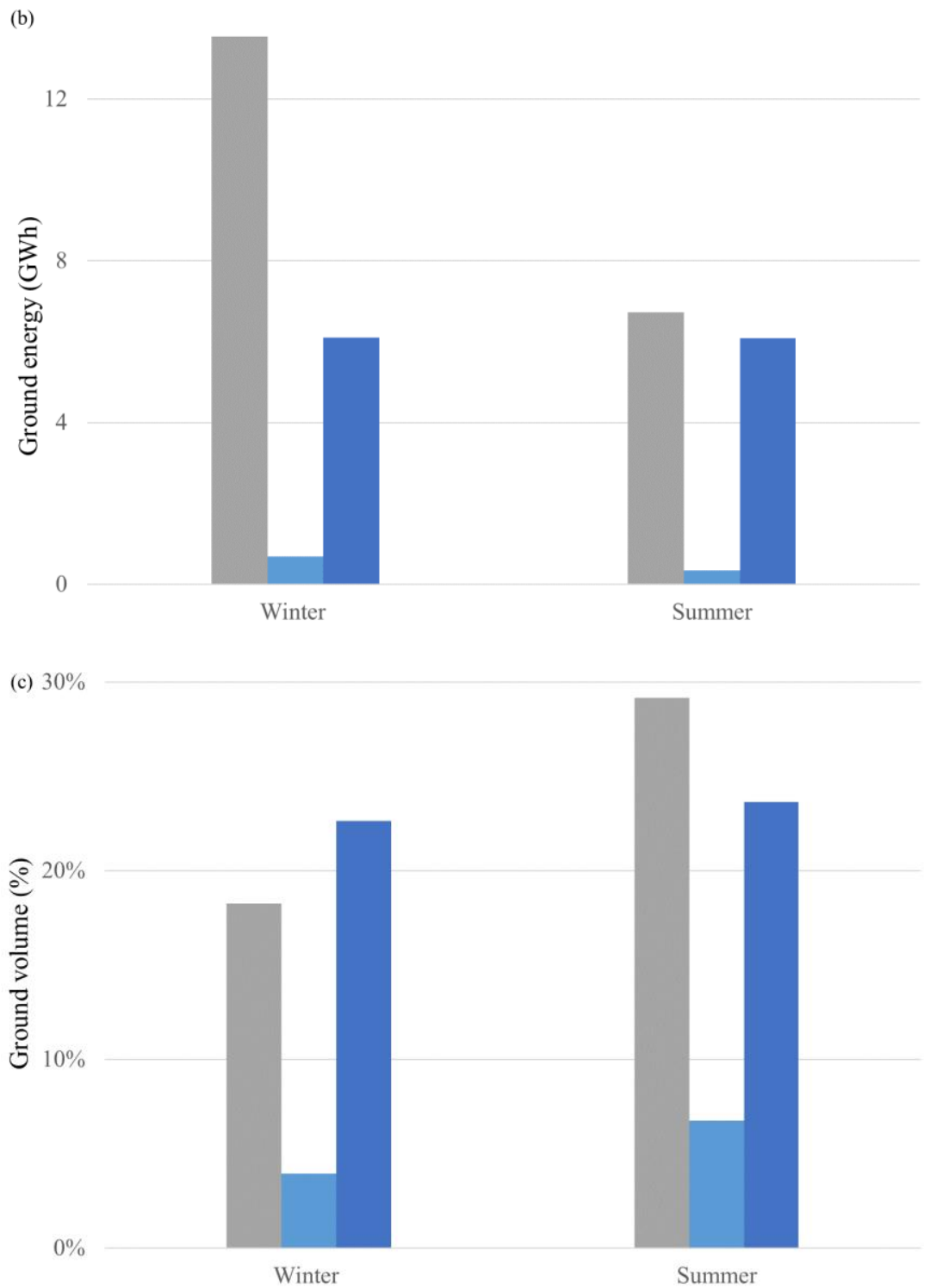

Figure 15. Seasonal variations in: a) ground temperature elevation, b) ground energy and c) percentage of the ground possessing a certain temperature elevation.

\section{Conclusions}

Ground temperature elevations in RBKC due to exposure to subsurface heat sources is numerically evaluated. To tackle the size issues of large scale heat transfer and fluid flow problems in the ground, a novel semi 3D finite element approach is developed. This study is limited to two main underground heat sources in the area: heated residential basements and train tunnels. In general, results show that the combined influence of density and arrangement of heat sources, coupled with geological and hydrological properties of the ground influences ground temperature elevations. It is observed that the arrangement and layout of underground structures become more crucial in ground thermal disturbance evaluations when the surrounding ground is highly impermeable, whereas geology and hydrogeology are the main parameters in temperature rise in permeable ground. Due to the local temperature elevation around structures constructed in impermeable ground, significantly higher density of heat sources is required to yield similar ground thermal disturbance to permeable ground. The potential ground energy at different parts of the borough indicates that in addition to the magnitude of the temperature elevation, the volume of the ground being affected by this temperature rise needs to be evaluated. The ground energy remains local with limited accessibility within immediate ground surrounding heat sources in highly impermeable soil, for which its accessibility increases by increasing the density of underground heat sources. In the permeable ground, 
however, the density and arrangement of heat sources are less influential while groundwater flow direction and rate plays a significant role in the extension of thermal disturbance in such ground conditions. The spatial dependency of ground temperature variations necessitates the understanding of combined effects of local ground and built environment characteristic on ground temperature elevation via large-scale ground modelling. To do so, information is gathered from diverse sources to assimilate the local properties of ground and underground built environment in RBKC and is utilized in a novel finite element ground modelling approach. Evaluating the ground temperature variability in large-scales, enables resilient planning of underground development by establishing policies to maintain ground thermal balance in the long-term. Moreover, accounting for local heat sources and their impact on ground temperature rise instead of the assumption of uniform ground temperature leads to a reliable local geothermal mapping, therefore, sustainable geothermal exploitation in the short and long-term. 


\section{References}

Baldwin, S., Holyord, E. \& Burrows, R., (2018). Mapping the Subterranean Geographies of Plutocratic London: Luxified Troglodytism?), Newcastle University

Batty, D., Barr, C. \& Duncan, P., (2018). What lies beneath: the subterranean secrets of London's super-rich, The Guardian, UK.

Attard, G., Rossier, Y., Winiarski, T. \& Eisenlohr, L., (2016a). Deterministic modeling of the impact of underground structures on urban groundwater temperature. Science of The Total Environment 572:986994.

Attard, G., Winiarski, T., Rossier, Y. \& Eisenlohr, L., (2016b). Impact of underground structures on the flow of urban groundwater. Hydrogeology journal 24(1):5-19.

Benz, S. A., Bayer, P., Menberg, K., Jung, S. \& Blum, P., (2015). Spatial resolution of anthropogenic heat fluxes into urban aquifers. Science of The Total Environment 524:427-439.

Epting, J., García-Gil, A., Huggenberger, P., Vázquez-Suñe, E. \& Mueller, M. H., (2017). Development of concepts for the management of thermal resources in urban areas-Assessment of transferability from the Basel (Switzerland) and Zaragoza (Spain) case studies. Journal of hydrology 548:697-715.

Epting, J. \& Huggenberger, P., (2013). Unraveling the heat island effect observed in urban groundwater bodiesDefinition of a potential natural state. Journal of hydrology 501:193-204.

Ferguson, G. \& Woodbury, A. D., (2004). Subsurface heat flow in an urban environment. Journal of Geophysical Research: Solid Earth 109(B2).

Ferguson, G. \& Woodbury, A. D., (2007). Urban heat island in the subsurface. Geophysical research letters 34(23).

Menberg, K., Blum, P., Schaffitel, A. \& Bayer, P., (2013). Long-term evolution of anthropogenic heat fluxes into a subsurface urban heat island. Environmental science \& technology 47(17):9747-9755.

Mueller, M. H., Huggenberger, P. \& Epting, J., (2018). Combining monitoring and modelling tools as a basis for city-scale concepts for a sustainable thermal management of urban groundwater resources. Science of The Total Environment 627:1121-1136.

Rivera, J., Blum, P. \& Bayer, P., (2017). Increased ground temperatures in urban areas: Estimation of the technical geothermal potential. Renewable Energy 103:388-400.

Ampofo, F., Maidment, G. \& Missenden, J., (2004). Underground railway environment in the UK Part 2: Investigation of heat load. Applied Thermal Engineering 24(5-6):633-645.

Cockram, L. J. \& Birnie, G. R., (1976). the ventilation of London underground railways. In 2nd International Symposium on the Aerodynamics and Ventialtion of Vehicle Tunnels.), Cambridge, England.

Furfano, D., Liebson, R. \& Brown, R., (2018). Now subway platfrom temperature feels like hell, too, New York Post.

Stephen, P., (2016). Cooling the Tube, Rail Magazine.

Rymarov, A. G. \& Davidsson, H., (2017). Analysis of heat losses in underground tunnels for preheating of ventilation air. International Journal of Civil Engineering and Technology 8(11):1172-1180.

Arola, T. \& Korkka-Niemi, K., (2014). The effect of urban heat islands on geothermal potential: examples from Quaternary aquifers in Finland. Hydrogeology journal 22(8):1953-1967.

Hähnlein, S., Bayer, P., Ferguson, G. \& Blum, P., (2013). Sustainability and policy for the thermal use of shallow geothermal energy. Energy Policy 59:914-925.

Herbert, A., Arthur, S. \& Chillingworth, G., (2013). Thermal modelling of large scale exploitation of ground source energy in urban aquifers as a resource management tool. Applied energy 109:94-103.

Zhu, K., Blum, P., Ferguson, G., Balke, K.-D. \& Bayer, P., (2010). The geothermal potential of urban heat islands. Environmental Research Letters 5(4):044002.

Mortada, A., Choudhary, R. \& Soga, K., (2018). Multi-dimensional simulation of underground subway spaces coupled with geoenergy systems. Journal of Building Performance Simulation:1-21. 
Zhang, Y., Soga, K. \& Choudhary, R., (2014). Shallow geothermal energy application with GSHPs at city scale: study on the City of Westminster. Géotechnique Letters 4(2):125-131.

Peters, T., (2018). Global quadrupling of cooling appliances to 14 billion could see staggering increase in world's energy consumption - new report.

Chua, K. J., Chou, S. K. \& Yang, W., (2010). Advances in heat pump systems: A review. Applied energy 87(12):3611-3624.

Lund, J. W., Freeston, D. H. \& Boyd, T. L., (2005). Direct application of geothermal energy: 2005 worldwide review. Geothermics 34(6):691-727.

Choudhary, R., (2012). Energy analysis of the non-domestic building stock of Greater London. Building and Environment 51:243-254.

Booth, A., Choudhary, R. \& Spiegelhalter, D., (2012). Handling uncertainty in housing stock models. Building and Environment 48:35-47.

GeoInformation, (2017a). UK Buildings. Verisk Analytics.

GeoInformation, (2017b). UK Map. Verisk Analytics.

RBKC, (2018). Planning and Building Control Portal/Planning Search.

Lane, M., (2011). How warm is your home, BBC Magazine, UK.

Gilbey, M., Duffy, S. \& Thompson, J., (2011). The potential for heat recovery from London underground stations and tunnels. In Proceedings of CIBSE technology and symposium. DeMontfort University.).

Transport for London, (2018). Tunnel Geometry

RBKC, (2004). Transport and streetscape policies. The Royal Borough of Kensington and Chelsea

Bidarmaghz, A. (2014). 3D numerical modelling of vertical ground heat exchangers. $\mathrm{PhD}$ Thesis, The University of Melbourne, Australia.

Bidarmaghz, A., Narsilio, G. A., Buhmann, P., Moormann, C. \& Westrich, B., (2017). Thermal Interaction Between Tunnel Ground Heat Exchangers and Borehole Heat Exchangers. Geomechanics for Energy and the Environment 10:29-41.

Makasis, N., Narsilio, G. A., Bidarmaghz, A. \& Johnston, I. W., (2018). Ground-source heat pump systems: the effect of variable pipe separation in ground heat exchangers. Computers and Geotechnics 100:97-109.

Price, S. J., Terrington, R. L., Busby, J., Bricker, S. \& Berry, T., (2018). 3D ground-use optimisation for sustainable urban development planning: A case-study from Earls Court, London, UK. Tunnelling and Underground Space Technology 81:144-164.

Statistical data set, (2017). Regional and local authority gas consumption statistics: 2005 to 2016. UK. 